\title{
A VÍZ KÜLÖNLEGES TULAJDONSÁGAI
}

\author{
Tasnádi Péter (iD), Weidinger Tamás \\ ELTE Meteorológiai Tanszék, 1117 Budapest, Pázmány Péter sétány 1/A \\ e-mail: tasi@caesar.elte.hu
}

Anomalous properties of water

\section{A cikket a szerzők Illy Judit emlékének ajánlják.}

\begin{abstract}
Water plays a fundamental role in the origination of life on the Earth, so almost every branch of sciences deal with it. Although water is a very common material and exists everywhere on the Earth both its physical and chemical properties are anomalous. That is why water plays a fundamental role in life, in the climate and weather, in the energy budget of the Earth, in the Sea currents, and so on.

In this paper, the anomalous physical properties of the water are summarized, and they are explained on the basis of the structure of the water. The structure of the water is created by the so-called H-bonds that are secondary chemical bonds connecting water molecules. It will be shown that the freezing-, boiling- and critical- point and also the phase transformation heats of the water are higher than the expected ones due to the secondary bonds. Similarly, these bonds are responsible for its high surface tension and the anomalous behavior of its density.
\end{abstract}

Keywords: anomalous properties of water, specific heat of water, latent heat, freezing and boiling point, H-bond; structure of water and ice

\section{Összefoglalás}

A víz a földi élet szempontjából alapvető jelentőségü anyag, a természettudományoknak szinte minden ága foglalkozik vele. Annak ellenére, hogy Földünkön mindenütt jelen van és hétköznapjainkban közönségesnek számító anyag, mind fizikai, mind kémiai tulajdonságai különlegesek. Emiatt játszik alapvető szerepet az élet keletkezésében, a Föld klímájának és a mindennapi időjárásnak az alakulásában, a Föld energiaháztartásában, a tengeráramlásokban és még számtalan egyéb folyamatban.

Ebben a dolgozatban a víz különleges fizikai tulajdonságait foglaljuk össze, a vízmolekulák közötti másodlagos kötések alapján (H-hidak) értelmezzük a víz sajátos tulajdonságait. Megmutatjuk, hogy a víz fagyási és párologási valamint kritikus hőmérséklete, továbbá fajhője és a latens hők is a vízmolekulák közötti másodlagos kötéseknek köszönhetően magasabbak a vártnál. Ugyancsak a másodlagos kötések miatt nagy a víz felületi feszültsége és viszkozitása is, de sűrűségének anomális viselkedéséért is ezek a kötések a felelősek.

Kulcsszavak: víz szokatlan tulajdonságai, víz fajhője, latens hője, fázisátalakulási hőmérsékletei, H-kötés, víz és jég szerkezete 


\section{Bevezetés}

A víz minden élőlény számára nélkülözhetetlen, központi szerepet tölt be a természetben, az iparban és mindennapi életünkben. A földi élet szempontjából alapvető jelentőségü anyag, a természettudományoknak szinte minden ága foglalkozik vele. Az élet keletkezésekor az aminosavak a villámok hatására keletkeztek az öslégkörben jelen lévő hidrogén, metán, ammónia, és vízgőz egyesülésével. Az élő szervezetek alkotórészei ugyancsak nagy százalékban vizes oldatok (vér, sejtek).

A víz összetételét kísérletileg Henry Cavendish (1731-1810) igazolta a legszebben (ő fedezte fel a hidrogént 1766-ban), a legteljesebb magyarázatot azonban Antoine Laurent Lavoisier (1743-1794) adta. Megállapította, hogy ha hidrogént oxigéngázban elégetnek, akkor víz keletkezik minden más termék nélkül. Bebizonyította, hogy a víz tömege a két felhasznált gáz tömegének összegével egyenlö. A víz tehát nem lehet más, mint a hidrogén és az oxigén vegyülete, a hidrogén égésterméke. Később a víz felbontásának egyik módját is felismerte. Izzó vasdarabok között vízgőzt vezetett át, és megállapította, hogy a víz oxigénje a vassal egyesül, a felszabaduló hidrogén pedig eltávozik.

Annak ellenére, hogy a víz Földünkön mindenütt jelen van és mindnyájunk számára ismert, hétköznapjainkban közönségesnek számító anyag, szigorúbb vizsgálatából és más anyagokkal való összehasonlításából kitünik, hogy tulajdonságai mind fizikai, mind kémiai szempontból különlegesek, s ezeknek a különleges tulajdonságoknak következtében játszik alapvető szerepet az élet keletkezésében, a Föld klímájának és a mindennapi időjárásnak az alakulásában, a Föld energiaháztartásában, a tengeráramlásokban és még számtalan egyéb folyamatban.

Ebben a dolgozatban a víz különleges fizikai tulajdonságait foglaljuk össze, elemezzük a víz szerkezetét és értelmezzük a belőle adódó sajátos tulajdonságokat. Az anomális tulajdonságokat Chaplin [1-www1.lsbu.ac.uk] honlapja alapján foglaljuk össze és felhasználjuk Tasnádi \& Illy (2018) kéziratos, valamint Weidinger \& Tasnádi (2015) cikkét. Chaplin a víz hetvennégy anomális tulajdonságát ismerteti, közülük itt csak azokat emeljük ki, amelyek a légköri és óceáni folyamatokban fontos szerepet játszanak. Megmutatjuk, hogy a víz fázisátalakulási hőmérsékletei és kritikus hőmérséklete, valamint különböző halmazállapotaiban fajhője és a latens hök is a vízmolekulák közötti másodlagos kötéseknek köszönhetően magasabbak a vártnál. Ugyancsak a másodlagos kötések miatt nagy a víz felületi feszültsége és viszkozitása is, de sürüségének anomális viselkedéséért is ezek a kötések felelősek.

\section{A víz különleges szerkezete}

\section{A víz összetétele}

Minthogy a hidrogénnek és az oxigénnek is vannak izotópjai, a vízmolekulában a hidrogén hatféle $\left(\mathrm{H}_{2}, \mathrm{HD}, \mathrm{D}_{2}, \mathrm{HT}, \mathrm{T}_{2}, \mathrm{DT}\right)$, az oxigén háromféle $\left({ }^{16} \mathrm{O},{ }^{17} \mathrm{O},{ }^{18} \mathrm{O}\right)$ izotópváltozatban vehet részt, így összesen tizennyolc féle vízmolekula létezik. A víz nagyrészt $\mathrm{H}_{2} \mathrm{O}$ összetételü, de például minden ötezredik vízmolekula HDO felépítésü. Szoros értelemben a deutérium-oxidot $\left(\mathrm{D}_{2} \mathrm{O}\right)$ nevezzük nehézvíznek, tágabb értelemben pedig a víznek minden olyan változatát, amelynek a molekulái a hidrogénnek vagy az oxigénnek valamelyik nehéz izotópját tartalmazzák. A természetes vizek elektrolízisekor a nehézvíz a maradékban halmozódik fel, ami lehetővé teszi elkülönítését (Nyilasi, 1976).

A nehézvíz szerkezete megegyezik a $\mathrm{H}_{2} \mathrm{O}$ molekuláéval. Minthogy azonban molekuláinak tömege nagyobb, ezért fizikai állandói eltérnek. Például a $\mathrm{D}_{2} \mathrm{O}$ összetételü nehézvíz fagyáspontja $+3,8^{\circ} \mathrm{C}$, forráspontja $101,43^{\circ} \mathrm{C}$, sürüsége $+4{ }^{\circ} \mathrm{C}$-on $1,11 \mathrm{~g} \mathrm{~cm}^{-3}$. $\mathrm{Az}$ 
izotóphatások nemcsak fizikai, de élettani szempontból is fontosak. A nehézvízben például nem csíráznak ki a növényi magvak, elpusztulnak benne a halak. A viszonylag kevés nehézvizet tartalmazó vízben is sokkal nehezebben élnek a növények és az állatok.

\section{A vízmolekula}

A továbbiakban a víz legegyszerübb alakjával, a $\mathrm{H}_{2} \mathrm{O}$-val foglalkozunk. A vízmolekula központi atomja az oxigén, a periódusos rendszer nyolcadik eleme (8 elektronnal és protonnal, 16-os tömegszámmal). Az oxigén elektronszerkezete elvileg például $1 s^{2} 2 s^{2} 2 p_{x}^{2} 2 p_{y}^{1} 2 p_{z}^{1}$ lehetne és a hidrogénatomok a $2 p_{y}$ és $2 p_{z}$ pálya elektronjaihoz csatlakozva hozhatnának létre kovalens kötést. Azonban nem ez történik! A vízmolekulában az oxigénatom tetraéderes szimmetriájú, úgynevezett $s p^{3}$ hibridállapotba kerül, azaz a $2 s$ és a három $2 p$ pályából négy egyenrangú elektronpálya keletkezik. A négy pályán összesen nyolc elektron fér el, kettőhöz a hidrogénatomok csatlakoznak $\sigma$-kötéssel, kettőn pedig nemkötő elektronpár helyezkedik el. (Bodor, 1968).
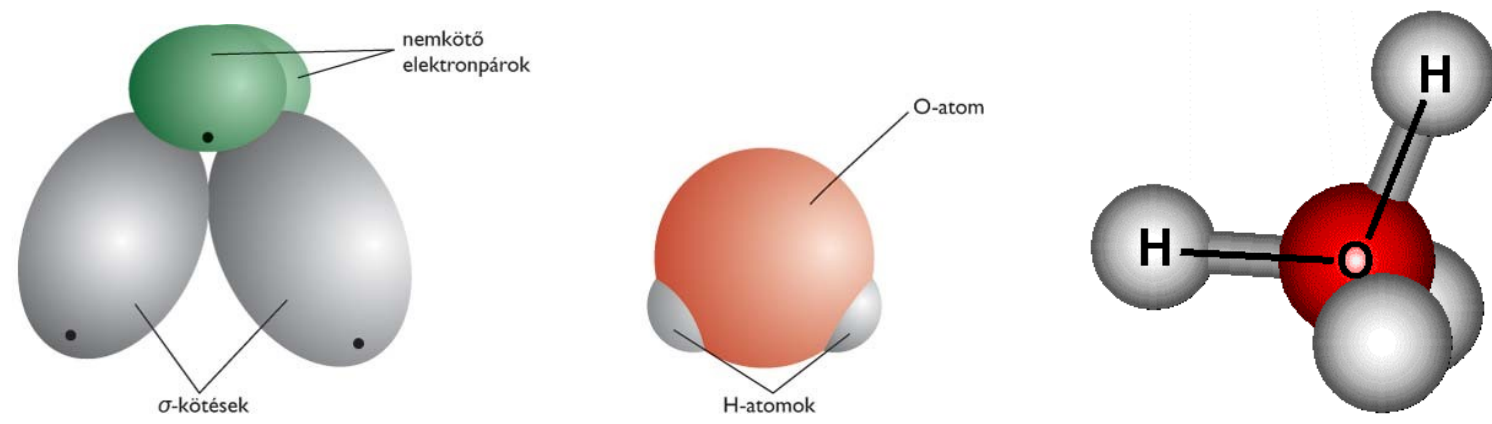

1. ábra: A vízmolekula négy elektronpárja, az oxigén és a hidrogén atomok elhelyezkedése (104 ${ }^{\circ}$-os szög).

Figure 1: Four electron pairs of water molecule, position of the oxygen and the hydrogens (104 ${ }^{\circ}$ angle).

Mivel az oxigén elektronegativitása nagy, az elektronburok erősen az oxigén mag felé húzódik. A tetraéderes szerkezet is kissé torzul, az oxigén nem pontosan a tetraéder közepére kerül, hanem kissé közelebb lesz a nemkötő elektronpárokhoz. Emiatt a hidrogénatomok kötési szöge a tetraéderes kötésböl következő 109,5 fok helyett csak 104 fok körüli (1. ábra). Az elektroneloszlás a kötés jellegén is változtat, tiszta kovalens kötés helyett az oxigén és hidrogén között ionos és kovalens kötés keveréke alakul ki.

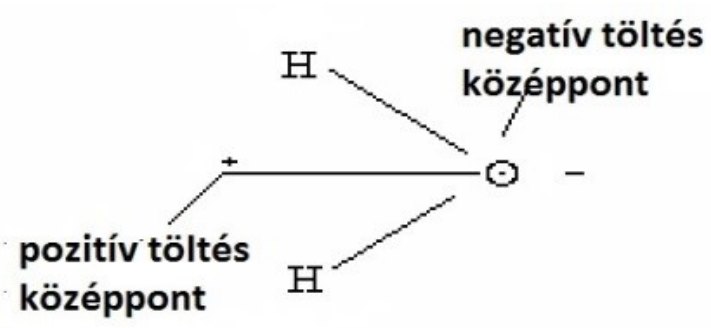

2. ábra: A dipólus szerkezetü vízmolekula.

Figure 2: The dipole structure of the water molecule. 
A V alakú vízmolekula pozitív és negatív töltésközéppontja nem ugyanoda esik, ezért a molekulának viszonylag nagy elektromos dipólmomentuma van: $\mu=6,17 \cdot 10^{-30} \mathrm{C} \mathrm{m}$. A dipól jelleg végeredményben annak a következménye, hogy a molekula egyik oldalán a nemkötő elektronpárok erős negatív, a másik oldalon pedig az elektronjaiktól szinte teljesen megfosztott hidrogénatomok protonjai erősen pozitív töltést mutatnak (2. ábra).

\section{A hidrogénhíd-kötés}

A dipólus szerkezet aszimmetrikus töltéseloszlása miatt a vízmolekulák könnyen kapcsolatba léphetnek egymással, az egyik molekula nemkötő elektronpárja és egy másik molekula hidrogén magja (a proton) között kémiai kötés alakulhat ki. Ez a hidrogénkötésnek (hidrogénhídnak) nevezett kötés csak annyiban különbözik az oxigénatomot „saját” hidrogénjével összekapcsolótól, hogy a kötéstávolság sokkal nagyobb és így a kötési energia sokkal kisebb. (3. és 4. ábra). A hidrogénhidak viszonylag erős kapcsolatokat hozhatnak létre a vízben, ugyanakkor mégsem állandósulnak, időről időre felbomolhatnak, és újra alakulhatnak (Marx, 1978).
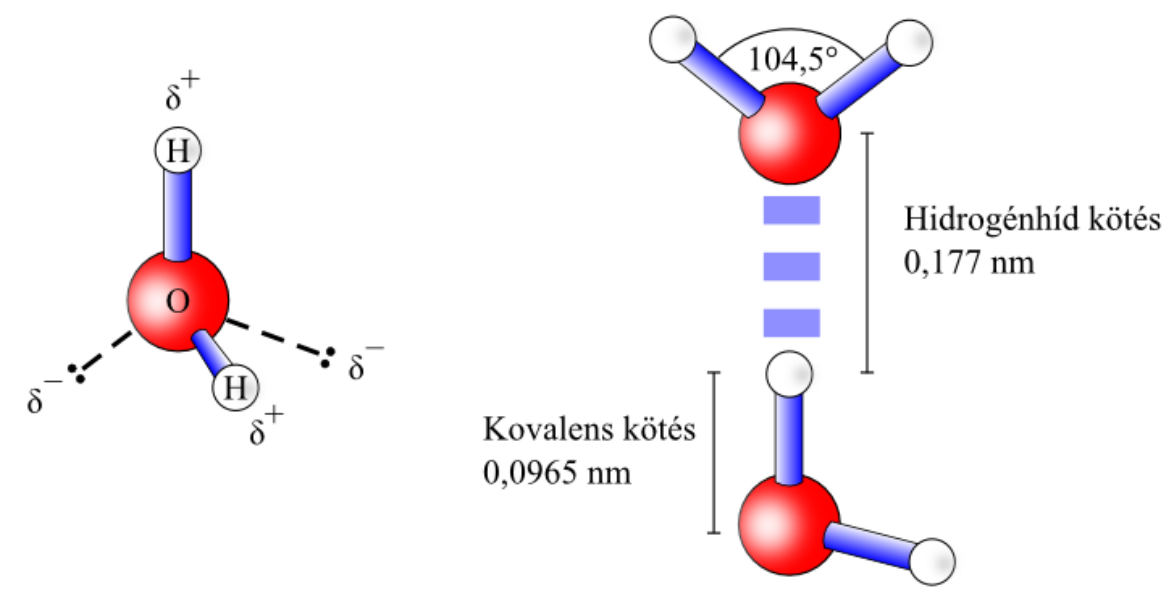

3. ábra: A poláros vízmolekula (bal oldalon) és a hidrogénkötés kötéstávolsága (jobb oldalon), ami nagyobb, mint a kovalens kötésénél.

Figure 3: Electrical polarization of water molecule (left) and the H- and covalent- bond length.

(The latter is longer).
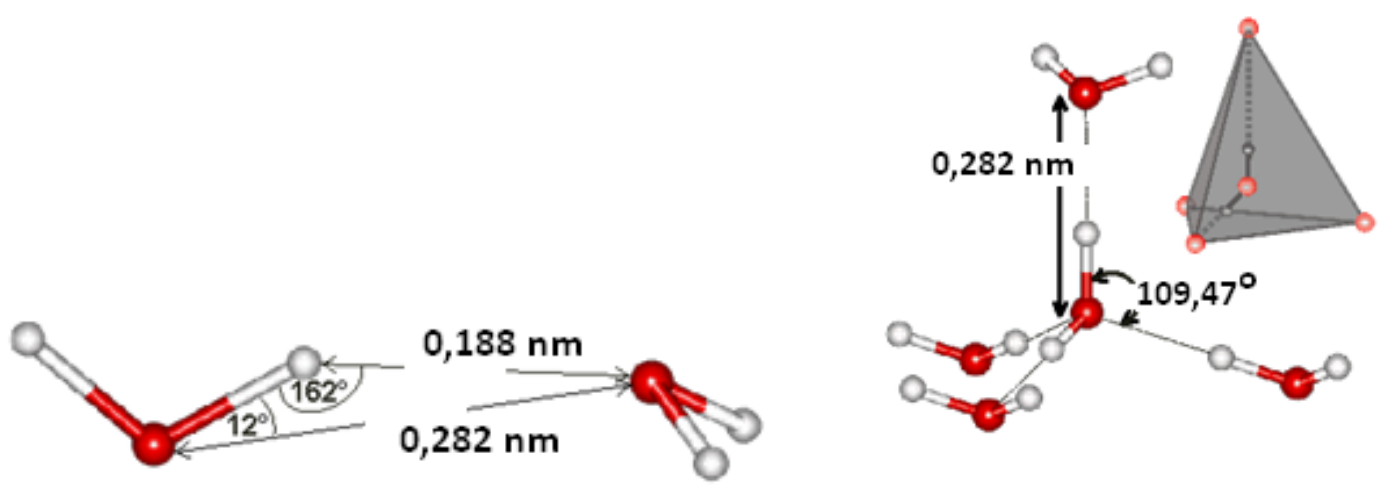

4. ábra: A tetraéderes szerkezetet kialakító hidrogénkötés.

Figure 4: H-bonding with the tetrahedral structure. 


\section{A víz klaszteresedése}

A vízben a kovalens kötés kötési energiája $492 \mathrm{~kJ}$ mól $^{-1}$, a hidrogénhídé $23,3 \mathrm{~kJ}$ mól ${ }^{-1}$, a szokásos másodlagos kémiai kötéseké pedig $5,5 \mathrm{~kJ}^{\text {mól}}{ }^{-1}$. A hidrogénhidak tehát nagyjából 50-szer gyengébbek, mint a valódi kémiai kötések, de nagyjából 5-ször olyan erősek, mint a másodlagos kémiai kötések. Érdemes még figyelembe venni, hogy a hidrogénhidak kötési energiája körülbelül 10 -szer akkora, mint a termikus fluktuációké $25^{\circ} \mathrm{C}$-on. Így, a vízmolekulák hidrogénkötésekkel lazán összekapcsolódó, ikozaéderes szimmetriájú kisebbnagyobb, lokalizált halmazokat, más szóval klasztereket alkotnak. A hidrogénkötések azonban a termikus mozgás eredményeképpen hol felbomlanak, hol újraalakulnak, így a klaszterek szerkezete és mérete sem állandó. Az ikozaéderes szerkezet termikus fluktuációk során változik, így kísérleti úton nem követhető nyomon, azonban molekuladinamikai szimulációkkal modellezhető. (Lásd például a következő szakdolgozatot: Ormándi (2014)).

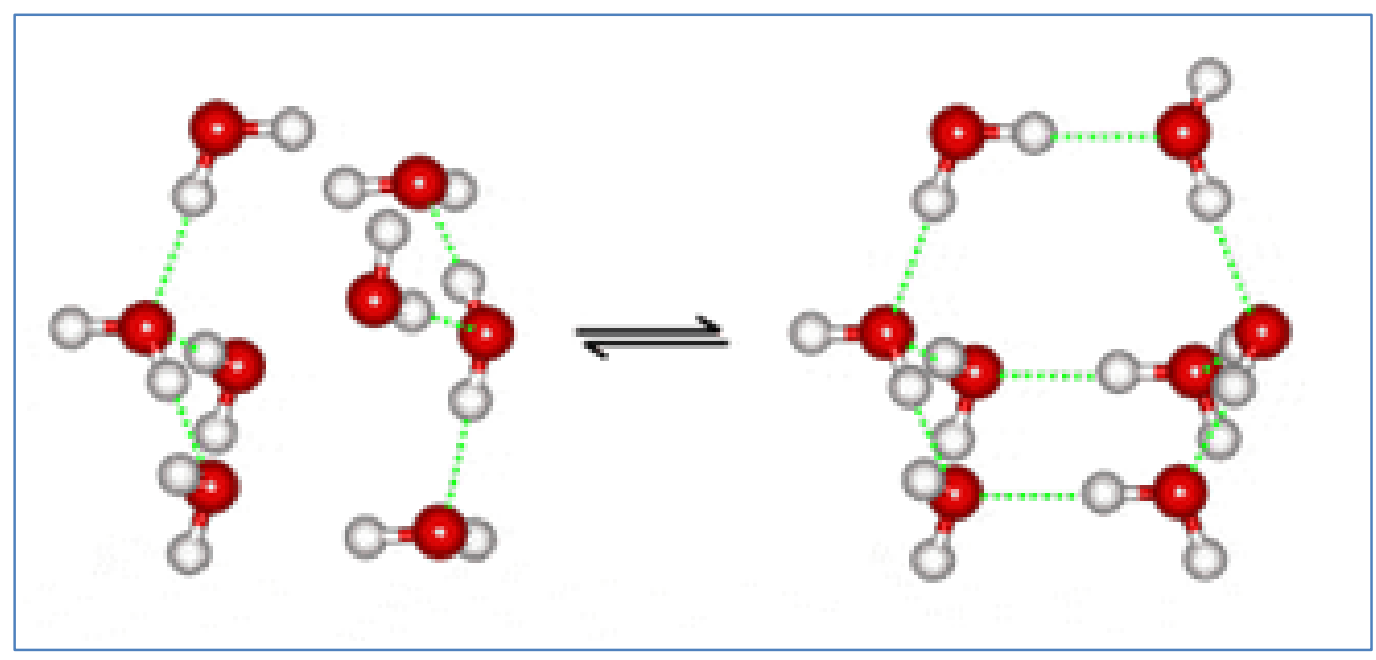

5. ábra: H-kötések változása a molekulák termikus mozgása miatt.

Figure 5: Change of H-bonds due to thermal motion.

Az 5. ábra vízmolekulából kialakuló csoportosulást és a csoportok átrendeződését szemlélteti. A hidrogénhidak feltételezése jelentősen segített a víz szerkezetéből fakadó anomális tulajdonságainak értelmezésében. Létezésük kézzelfogható bizonyítása azonban csak 2013-ban sikerült, amikor Zhang et al. (2013) kontaktus nélküli atomerö-mikroszkóp (NC-AFM) segítségével a 8-hydroxyquinolin vegyületben a valódi térben felvették a hibrid állapot elektronsürüségének az eloszlását (6. ábra.)

A víznek számos különleges tulajdonsága van, emiatt sok területen felhasználható mind az épített, mind pedig a természetes környezetünkben. Ezek a tulajdonságok a vízmolekulák együttesének tulajdonságai, ezért értelmezésük csakis a molekulák között ható erők, a másodrendü kötések figyelembevételével lehetséges.

\section{A jég szerkezete}

Ha a víz megfagy, akkor a jégkristályban az egyes oxigénatomokat négy másik oxigénatom veszi körül tetraéderes szimmetriában. Az oxigének távolsága 27,6 nm, közöttük egy-egy hidrogénatom van, amely mindkét oxigénatomhoz kapcsolódik, az egyikhez erősebben (kovalens kötéssel), a másikhoz gyengébben (hidrogénhíddal). Ennek megfelelöen a jégkristályban a hidrogénatommag távolsága az egyik oxigénatom magjától 10,1 nm, a másiktól 17,5 nm. A jégben tehát minden oxigénatom két hidrogénatommal szoros, kettővel 
pedig lazább kapcsolatban áll. Ahogyan azt a 7. ábrán is látjuk, a jégkristály egészét kémiai kötések hálózata köti össze (lásd külön is a 7a ábrát).

A jég hexagonális elrendezésű lapjai azonban molekuláris szinten nem síkfelületek, és a hexagonális szimmetria is torzul. Elöbbit az oxigénatomok körüli térbeli tetraéderes kötéselrendeződés, utóbbit a kovalens kötések és a hidrogénhíd kötések eltérő kötéshossza okozza. Ezért nevezik a jég szerkezetét kvázihexagonálisnak.
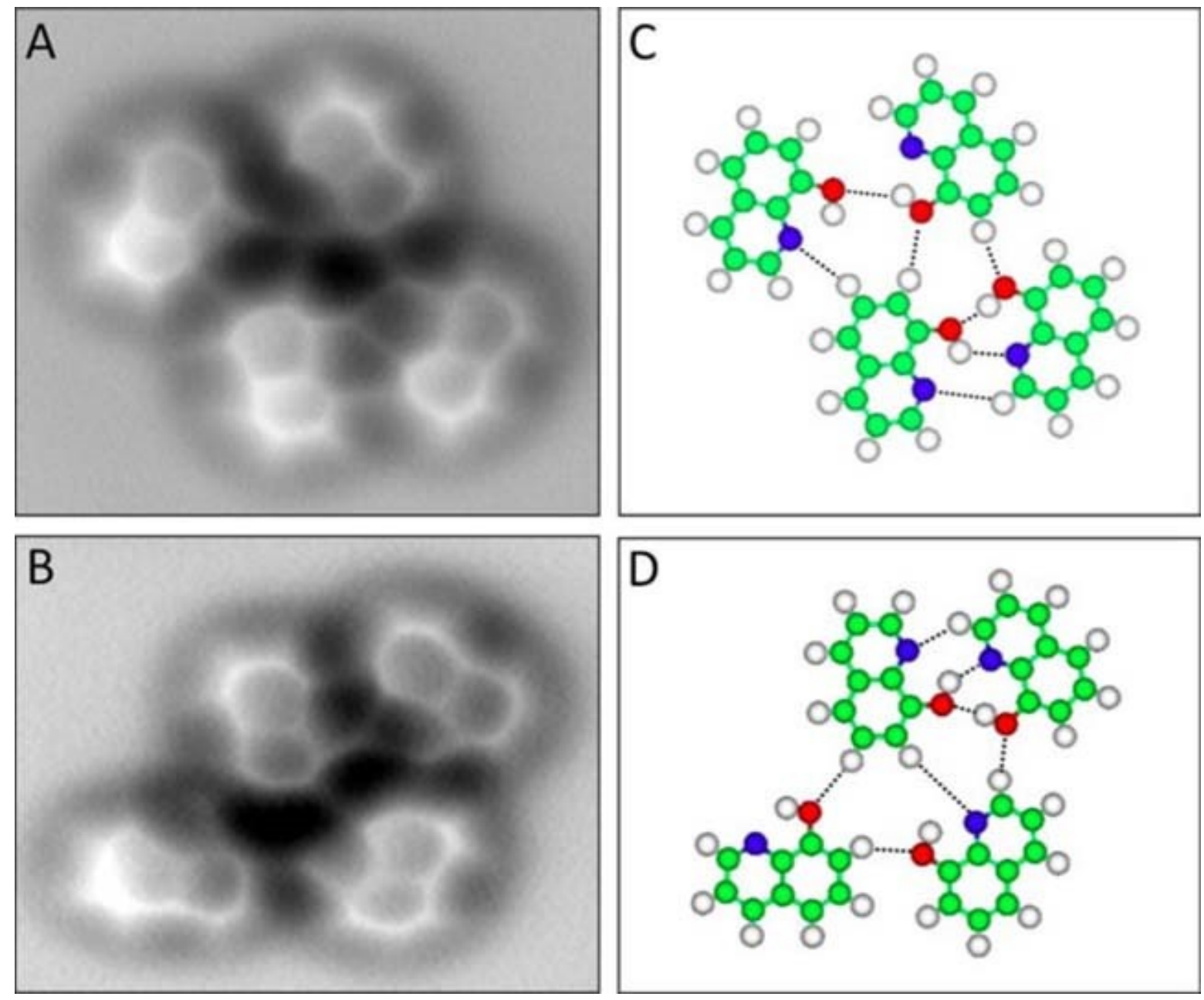

6. ábra: Elektroneloszlás NC-AFM kontrasztja (A és B) és a megfelelő atomszerkezet (C és D) sematikus képe (piros oxigén, zöld szén, kék nitrogén üres hidrogén,

a pontozott vonalak jelzik a H-kötéseket).

Figure 6: NC-AFM contrast of the electron distribution (A and B) and the schematic picture of the atomic structure corresponding to them (C and D) (red, green, blue and white circles indicate oxygen, carbon, nitrogen and hydrogen atoms, respectively. dashed lines indicate hydrogen bonds. 


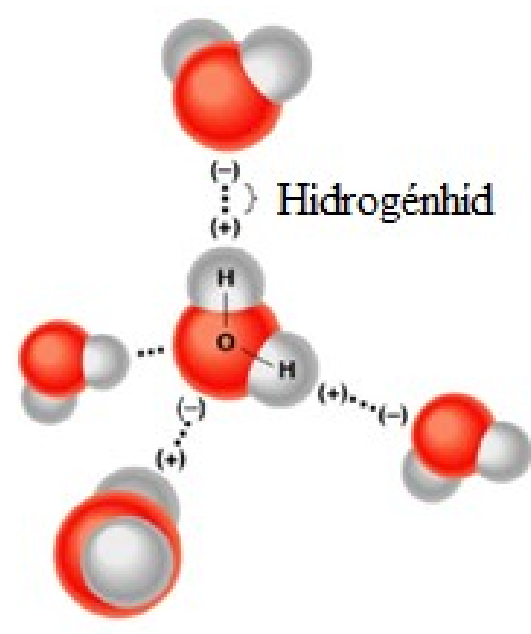

a)

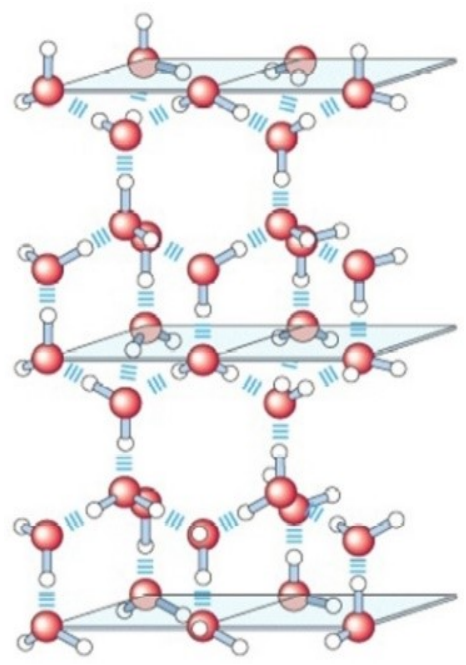

b)

7. ábra: a) Tetraéderes szimmetria oxigénatom körül,

b) A jég H-kötésekkel kimerevített „kvázi”-hexagonális kristályszerkezete.

Figure 7: a) Tetrahedral symmetry around an oxygen atom.

b) Quasi hexagonal crystal structure of ice with frozen H-bonds.

\section{A víz halmazállapotai}

A $\mathrm{H}_{2} \mathrm{O}$ az egyetlen vegyület, amely természetes körülmények között mindhárom halmazállapotban egyszerre előfordulhat a föld légkörében. A három halmazállapot és a halmazállapot-változások tulajdonságai legegyszerübben a víz fázisdiagramja alapján tekinthetök át (8. ábra).

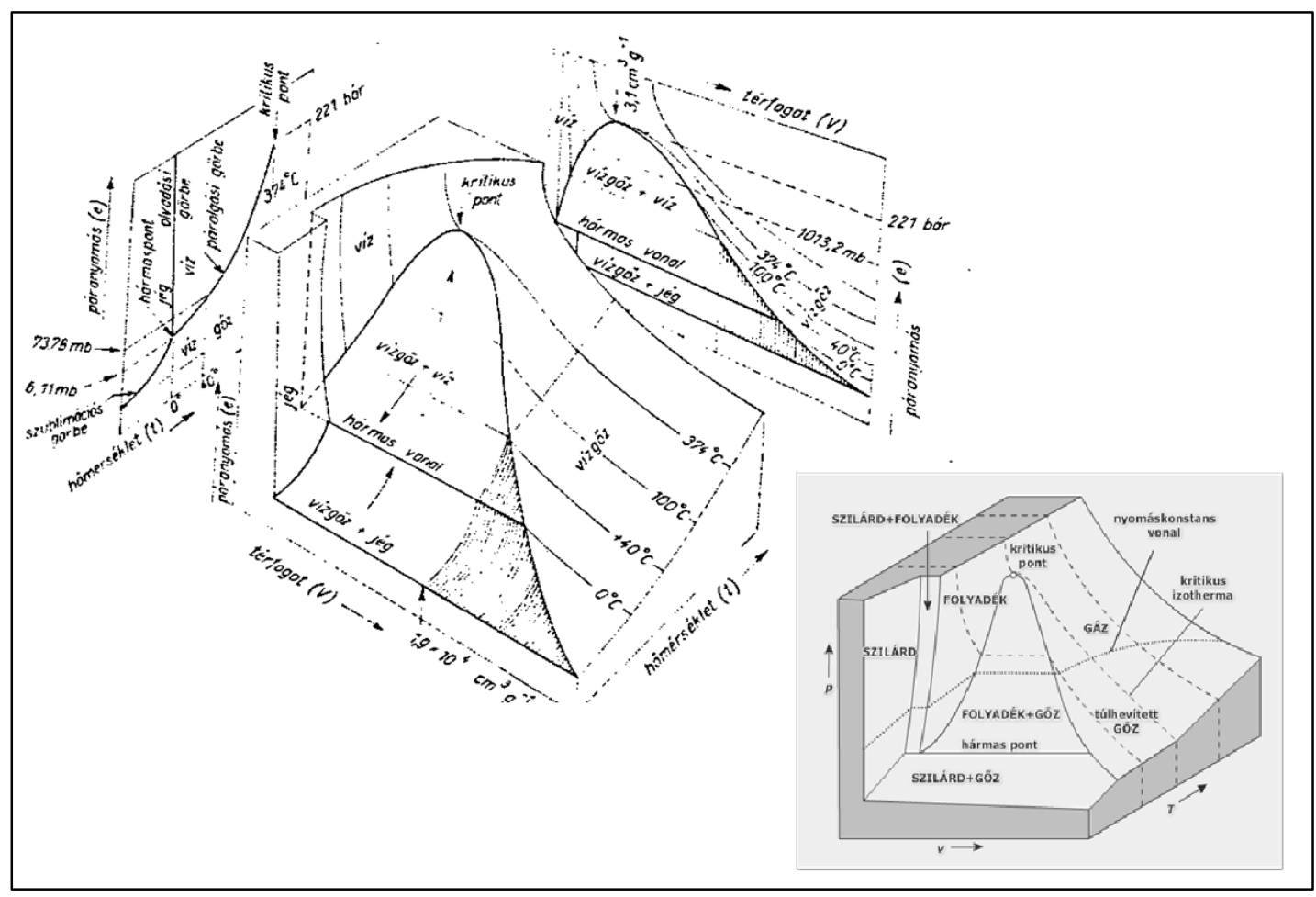

8. ábra: A víz háromdimenziós fázisdiagramja Czelnai (1979) és Bihari (2012) nyomán.

Figure 8: 3D phase diagram of water after Czelnai (1979) and Bihari (2012). 
A 8. ábra a $\mathrm{H}_{2} \mathrm{O}$ háromdimenziós egyensúlyi fázisdiagramját mutatja, a 9. ábrán bal oldalt pedig a szokásos fázisdiagram látható, ami a háromdimenziós fázisdiagram nyomás hőmérséklet $(p, T)$ felületre vett vetülete. A 9. ábra jobboldalán ebből a vetületből emeltük ki a közönséges körülményekre vonatkozó részt. A fázisdiagram a szilárd fázisban sokféle szerkezetü jég kialakulásának lehetőségét, és ennek megfelelően a bonyolult fázisátalakulások rendszerét mutatja be. Mindez azonban olyan hőmérsékleti és nyomás tartományban valósulhat meg, ami messze van a légköri nyomás és hőmérséklet tartományától.

Ezért a diagram légkörben elérhető tartományáról kivágatot készítettünk. A diagram jól mutatja, hogy a közönséges légköri körülmények között a jég is csak egyféle fázisban létezhet. A fázisdiagramról leolvasható, hogy a nyomás változásával a jég-víz fázisátalakulás hőmérséklete gyakorlatilag nem változik, $273 \mathrm{~K}$ marad.

Az egyensúlyi fázisdiagram azonban még a légköri állapotok tartományában sem írja le reálisan a $\mathrm{H}_{2} \mathrm{O}$ halmazállapot-változásait. A víz nagymértékben túlhüthető és túlfüthető. Túlhütött gőz a légkörben nem létezhet, a túlhült víz azonban jelentős szerepet játszik a csapadékképzödésben. A 10. ábra a víz metastabil tartományait mutatja.

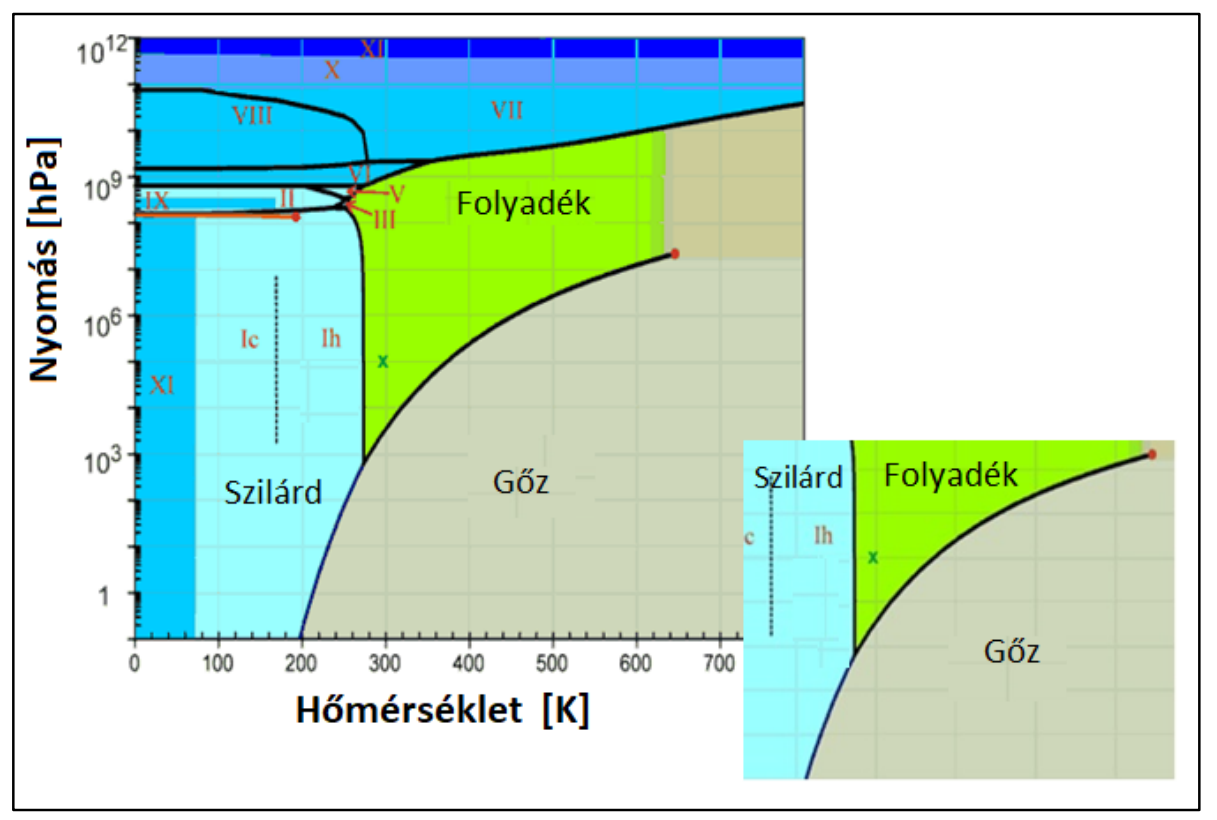

9. ábra: Fázisdiagram a $p-T$ síkon (Wikipédia nyomán).

Figure 9: Phase diagram in $p-T$ plane (after Wikipedia).

A víz túlhülése a hidrogénhidak stabilizáló hatásának a következménye. A fagyás általában jégmagok képződésével kezdődik. Nagyon tiszta vízben a magok homogén elrendeződésben keletkező molekuláris csoportosulások. (Ezt nevezzük homogén nukleációnak.) A víz azonban többnyire szennyező anyagokat is tartalmaz. E szennyezők a szilárd halmazállapot csírái. A szennyezők eloszlása a felhővízben nem homogén, ezért ezt a folyamatot inhomogén nukleációnak nevezzük.

A tapasztalat szerint a fagyásponthoz közeli hömérséklet-tartományban mindig inhomogén nukleációval jön létre a jég. Amennyiben a vízben kevés a szennyezö, akkor ebben a tartományban a víz túlhüthető. A túlhüthetőség határa a fagyás homogén nukleációval való bekövetkezésének hőmérséklete $\left(-41^{\circ} \mathrm{C}\right)$, azaz az a hőmérséklet, amelyen a vízmolekulák szennyezők nélkül is spontán módon csoportosulnak. 
A felhöcseppecskék - különböző koncentrációjú oldatokként $-0{ }^{\circ} \mathrm{C}$-nál alacsonyabb hőmérsékleten fagynak meg. A légkörben $-10--15^{\circ} \mathrm{C}$-ig többségében túlhült vízcseppekböl álló felhők vannak (Geresdi, 2004).

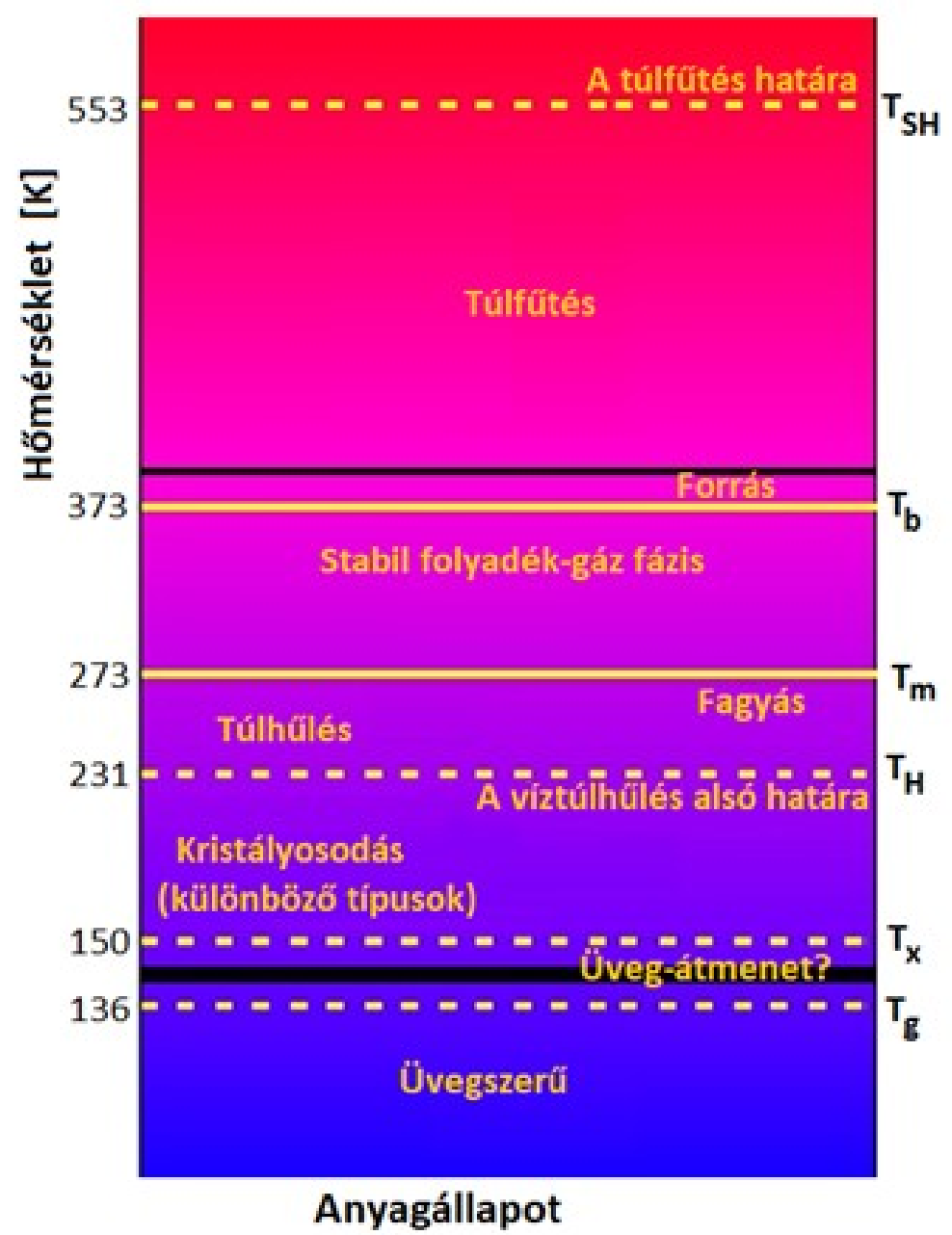

10. ábra: A víz metastabil tartományai. $T_{S H}, T_{b}, T_{m}, T_{H}, T_{x}$ és $T_{g}$ rendre a túlfütés, a forráspont, a fagyás, a víz túlhütésének kritikus értéke, illetve az üvegszerü átmenet felső és alsó határhőmérséklete.

Figure 10: Metastable regions of water. $\left(T_{S H}, T_{b}, T_{m}, T_{H}, T_{x}\right.$ and $T_{g}$ superheating-, boiling-, freezingand supercooling-point, as well as the upper and lower limit of the transformation temperature to the glassy state.

\section{A víz különleges termikus és mechanikai tulajdonságai}

\section{Magas fázisátalakulási hömérsékletek}

A tapasztalat szerint az azonos szerkezetü, de különböző méretű és tömegü molekulák között az összetartó erők annál nagyobbak, minél nagyobb a molekula tömege. Az oxigén (O), a kén (S), a szelén (Se) és a tellúr (Te) a periódusos rendszerben egymás alatt, ugyanabban az oszlopban található, így külső elektronhéjuk azonos szerkezetü. Tanulságos összevetni a víz $\left(\mathrm{H}_{2} \mathrm{O}\right)$, a kén-hidrogén $\left(\mathrm{H}_{2} \mathrm{~S}\right)$, a szelén-hidrogén $\left(\mathrm{H}_{2} \mathrm{Se}\right)$ és a tellúr-hidrogén $\left(\mathrm{H}_{2} \mathrm{Te}\right)$ olvadásés forráspontját (11. ábra; Nyilasi, 1976). 
Bár a kén-, a szelén- és a tellúratomok tömege és mérete az oxigénatoméhoz képest egyre nagyobb, atomszerkezetük hasonló, a legkülső elektronhéjon mindegyiküknek hat elektronja van. Ebből következik, hogy mindegyikük két hidrogénatommal képez molekulát. A molekulák tömege a

$$
\mathrm{H}_{2} \mathrm{O}<\mathrm{H}_{2} \mathrm{~S}<\mathrm{H}_{2} \mathrm{Se}<\mathrm{H}_{2} \mathrm{Te}
$$

sorrendben nö. A 10. ábráról leolvasható ezeknek a vegyületeknek az olvadás- és forráspontja a molekulatömeg függvényében, tehát az a hőmérséklet-tartomány is, amelyben $10^{5} \mathrm{~Pa}(1000 \mathrm{hPa})$ nyomás esetén cseppfolyós halmazállapotúak.

Figyelembe véve a dipólus molekulák közötti összetartó erőt, ezen adatok alapján a víz forráspontjának $-80{ }^{\circ} \mathrm{C}$-on, fagyáspontjának pedig $-100{ }^{\circ} \mathrm{C}$ hőmérsékleten kellene lennie. A valóságban azonban a víz forráspontja lényegesen magasabb és a jég olvadáspontja is mintegy $100 \mathrm{~K}$-nel magasabban van a vártnál. A jégben minden vízmolekula négy hidrogénkötést hoz létre (kettőt donorként, kettőt akceptorként), és viszonylag stabil és statikus kristályszerkezet keletkezik. A jég kötéseinek feltörése nagy energiát igényel, így az olvadáspont magasabb hőmérsékletre kerül. A folyékony vízben is sok hidrogénhíd van. (Minél alacsonyabb a hőmérséklet, annál több.) A H-hidak megakadályozzák a molekulák kilépését a víz felszínéről, azaz a páranyomás csökken. A forrás azonban csak akkor következhet be, amikor a páranyomás eléri a külső nyomást. Emiatt a forráspont magasabbra kerül.

Érdemes egy pillantást vetni a víz kritikus pontjára is más vegyületekkel összehasonlítva (12. ábra)! A víz kritikus pontja mintegy $250 \mathrm{~K}$-nel magasabban van mint a periódusos rendszer VIA oszlop elemeinek hidridjeivel való összevetésből adódna, de a IVA elemeinek hidridjeiéhez képest is sokkal magasabban van. Ezt azzal magyarázhatjuk, hogy a kritikus pont csak akkor érhető el, ha a vízmolekulák közötti kölcsönhatás meghatározott küszöb alá esik. A vízmolekulák hőmozgása a molekulák közötti H-hidakat csak jóval magasabb hömérsékleten képes felszakítani, mint a többi anyagokat összekötő Van der Waals-féle kötéseket.

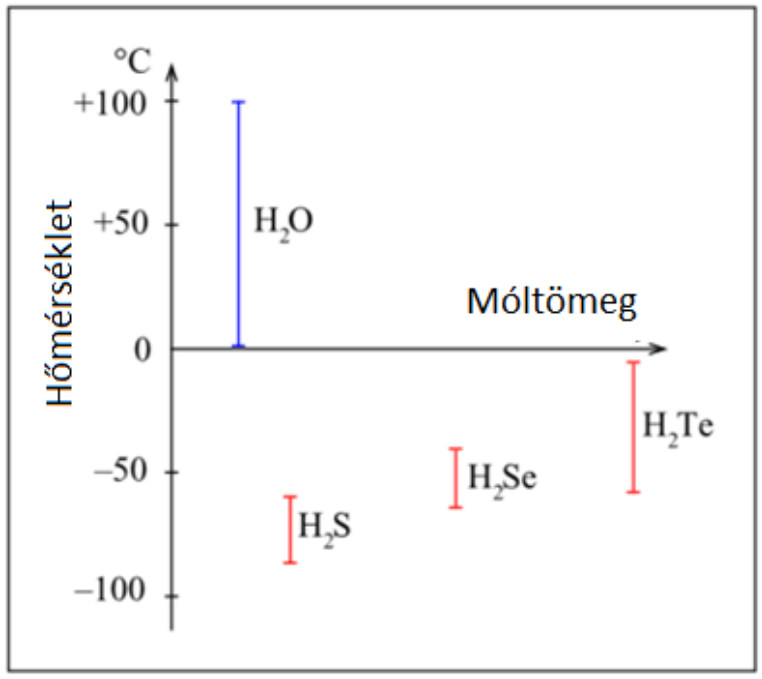

11 ábra: A vízhez hasonló molekulaszerkezetü vegyületek olvadás- és forráspontja a molekulatömeg függvényében.

Figure 11: Melting- and freezing-point of some materials which have water like molecule structure. 


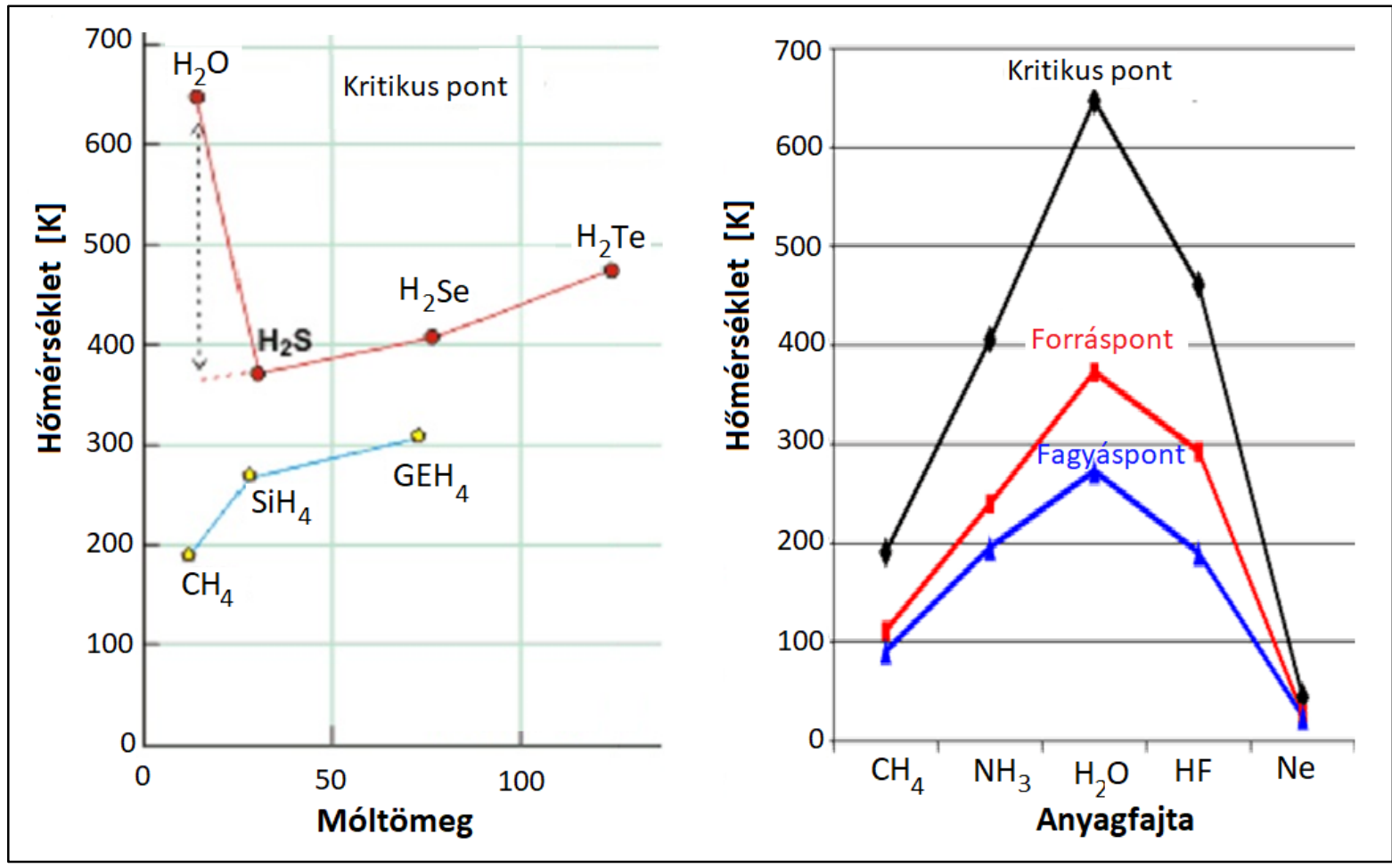

12. ábra: A víz kritikus pontja a IVA és VIA oszlop elemeinek hidridjeivel (balra) és izoelektronos molekulákkal (jobbra) (Chalmers nyomán, http://wwwl.lsbu.ac.uk/water/phase_anomalies.html\#Cpt).

Figure 12: Comparison of the Critical point of water with that of the IVA és VIA hydrids (left) and with isoelectronic molecules (right) (after Chalmers http://www1.lsbu.ac.uk/water/phase_anomalies.html\#Cpt

\section{Magas fajhö és latens hö}

Az ammóniától eltekintve, a folyadékok között a víz fajhője a legnagyobb. A tömegegységnyi vízre (folyadék) vonatkozó állandó térfogaton $\left(c_{V}\right)$ és állandó nyomáson $\left(c_{p}\right)$ vett fajhö rendre $4137,5 \mathrm{~J} \mathrm{~kg}^{-1} \mathrm{~K}^{-1}$ és $4181,9 \mathrm{~kg}^{-1} \mathrm{~K}^{-1}\left(25^{\circ} \mathrm{C}\right.$-on $)$. A víz melegítése során a molekulák hőmozgása erősödik és egyre több és több H-híd szakad fel. Ez nagy energiát igényel. Az is mutatja, hogy a víz (folyadékvíz) fajhőjében a H-hidak felszakítása nagy szerepet játszik. Teljesül továbbá, hogy a jég és a vízgőz fajhője nagyjából fele akkora, mint a vízé (Sem a gőz, sem a jég melegítésekor nem szakadnak fel H-hidak.). Amikor a víz hül, akkor a magas fajhő miatt sok energia szabadul fel. A víz fajhője a szárazföldet felépítő anyagokénál is kétszer, háromszor nagyobb (Az univerzum egyik legnagyobb fajhöjü anyaga.). Emiatt a tengervíz is lassabban és kevésbé melegszik fel, valamint lassabban és kevésbé hűl le, mint a szárazföld: a víz a nyáron elraktározott hőmennyiséget télen lassan bocsátja ki (óceáni éghajlat). Ennek egyik legfontosabb következménye, hogy a szomszédos szárazföldi területek éghajlatára kiegyenlítő hatással van (télen füt, nyáron hüt). Hozzájárul ehhez az is, hogy a tengervíz sokkal nagyobb mélységig melegszik fel, mint a szárazföld, mert a napsugarak $100 \mathrm{~m}$ mélyre is lehatolhatnak a vízbe. A víz hullámzása és áramlása tovább növeli a felmelegedő vízréteg vastagságát. Az Északi-tengerben például a nyár folyamán 30-40 m vastag vízréteg melegszik át. A hullámzás átkeverő hatása miatt eddig a mélységig nagyjából azonos a víz hőmérséklete, lejjebb azonban még a legmelegebb nyárban is ugrásszerüen csökken. 
A H-kötésnek köszönhetően a víz párolgási hője a legnagyobb a molekuláris folyadékok között. A forrásponton a H-hidaknak még mintegy 75\%-a létezik és mivel a légnemüvé váláshoz lényegében minden $\mathrm{H}$-hidat fel kell szakítani, a latens hő nagyon nagy $\left(2257 \mathrm{~kJ} \mathrm{~kg}^{-1}\right)$. A hőmérséklet csökkenésével a H-hidak száma is nő, így a víz párolgáshője még nagyobb lesz. Természetesen a szublimációs hö, ami jó közelítéssel a fagyáshő és a párolgási összege, szintén kivételesen magas. A légköri vízről szóló cikkünkben (Weidinger \& Tasnádi, 2020) megmutatjuk, hogy a nagy latens hö miatt a víz légköri körforgalma során szállított energia több mint 20\%-át teszi ki a tejes légköri energiaforgalomnak.

\section{A vízsürüség anomáliái}

A víz egyik sajátos tulajdonsága, hogy szilárd állapotában kisebb a sürüsége, mint folyadék halmazállapotban: a jég úszik a víz felszínén. Ez a ritka tulajdonság a víz szerkezetének ismeretében érthetővé válik. A vízmolekulák közötti H-kötés nem állandó, a hőmozgásnak köszönhetően folyamatosan felszakad és újraalakul. Hőmérséklettől függő verseny alakul ki a hőmozgás és a hidrogénkötés között: a H-kötés a rendezettség, a hőmozgás pedig a rendezetlenség irányában müködik. Magas hőmérsékleten a hőmozgás dominál, alacsonyabb hőmérsékleten pedig a stabilizáló hidrogénhidak. A hőmérséklet csökkenésével a hőmozgás kisebb mértékü lesz, ami a sürüség növekedésének irányába hat. Emiatt a hidrogénhidak egyre kevésbé szakadnak fel, stabilizálódnak. Ez a stabilizálódás, ha dominánssá válik, akkor már a sürüség csökkenését segíti, mivel a hidrogénkötések hosszabbak a kovalens kötésnél, és „,kifeszítik” a szerkezetet (13. ábra).

A két ellentétes hatás eredményeképpen a víz sürüsége $+4{ }^{\circ} \mathrm{C}$-on a legnagyobb. Ez a sürüségmaximum a fagyáspont közelében van, a víz további hülésekor a víz sürüsége már csökken. A víz sürüségének fagyás közben történő csökkenése térfogat növekedéssel jár. Ez a 9\%-os térfogat-növekedés okozza a befagyott édesvizü tavak felszínén a jég repedését, az ún. rianást. Hasonló folyamat okozza a kőzetek repedését is: a repedésekbe nyáron beszivárgó víz télen jéggé fagy, térfogata megnő, az így keletkezett nyomás tovább feszíti a repedést (14. ábra).

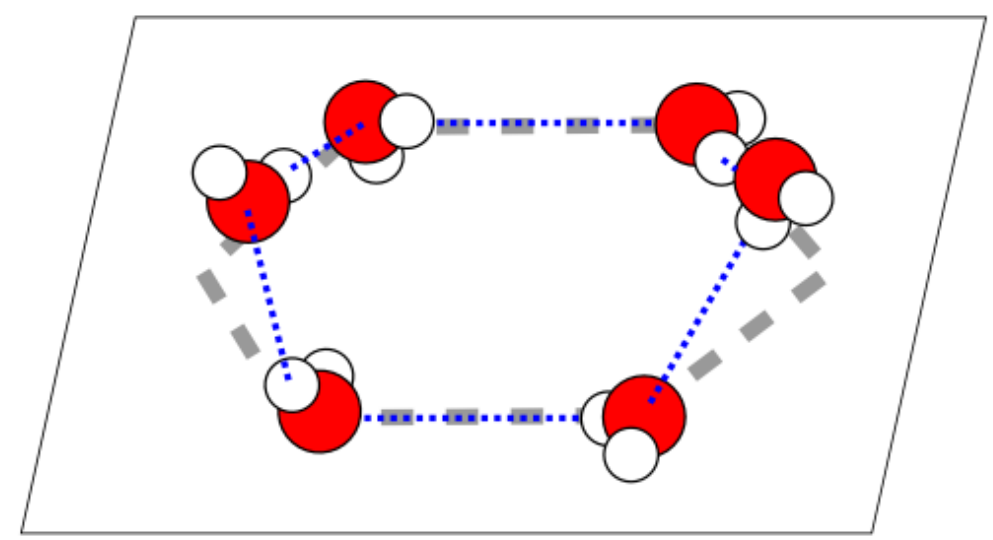

13. ábra: A H-híd kötéstávolsága nagyobb, mint a kovalens kötésé, ezért atomi skálán a hexagonális forma nem síkidom.

Figure 13: H-bond length higher than covalent bond length therefore in atomic scale the hexagonal form in clusters is not a plane figure. 

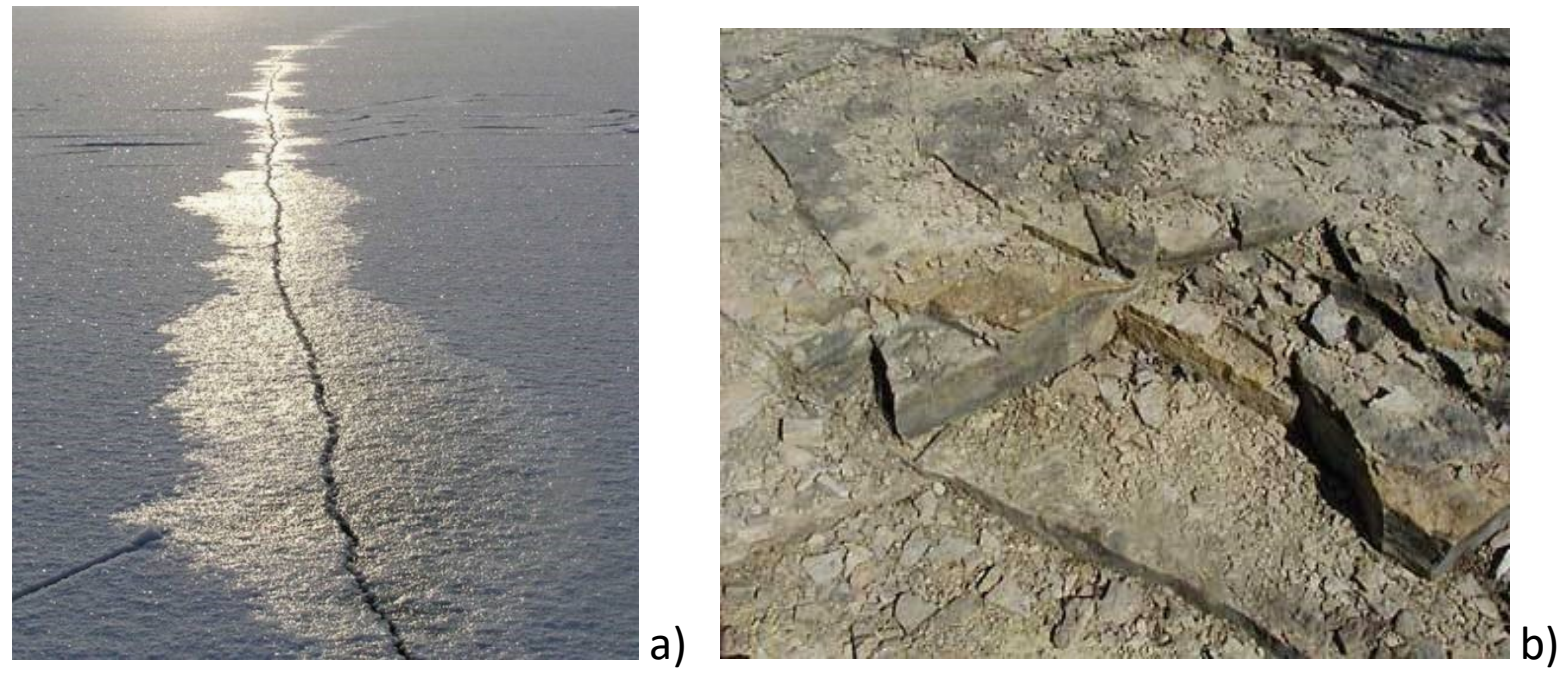

14. ábra: a) Rianás a Balaton jegén, b) Közetek repedése.

Figure 14: a) Split on the Balaton ice b) Rock cracking.

Télen az édesvízi tavak befagyásakor a felszín közelében a hőmérséklet a mélységgel növekszik, ami a vízi élővilág számára rendkívül kedvező (15. ábra). A tavak nem alulról, hanem felülről fagynak be, mivel a víznek nagyobb a fajhője, mint a levegőnek, így lassabban hül le. A külső hideg levegő hatására a vízfelszín fagy be először. A jégréteg nagyon lassan vastagszik, a jég rossz hővezető képessége miatt. A víz anomális sürüségváltozása miatt a $+4{ }^{\circ} \mathrm{C}$-os víz lesz legalul.

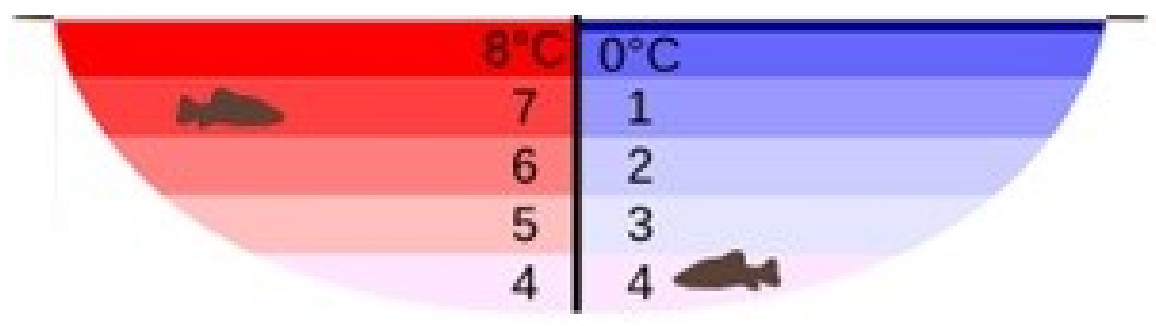

15. ábra: Télen a halak mélyebbre úszva áttelelnek a befagyott tóban.

Figure 15: Fishes swim deeper in the lake to survive the winter.

Az édesvizű tavaknál tapasztalt „fordított” rétegződés a tengerekben nem jön létre, a tengervíz hömérséklete a mélységgel monoton csökken. Ennek oka a tengervíz sótartalma. A vízben oldott só csökkenti a víz fagyáspontját $\left(T_{f}\right)$ és a maximális sürüséghez tartozó hömérsékletet $\left(T_{m}\right)$ is, de nem egyforma mértékben (16. ábra).

A tiszta víz maximális sürüséghez tartozó hőmérséklete és fagyáspontja nem esik egybe. A 16. ábra jól mutatja, hogy mind a fagyáspont, mind a maximális sürüséghez tartozó hőmérséklet lineárisan csökken a sótartalom függvényében. A sótartalom növelésével egészen a 24,7\%o koncentrációig a maximális sürüséghez tartozó hőmérséklet a tiszta vízhez hasonlóan magasabb, mint a fagyáspont, a két egyenes ennél a sótartalomnál metszi egymást. A tengervíz átlagos sótartalma 35\%o, ennél a sótartalomnál a fagyáspont már magasabb, mint a maximális sürüséghez tartozó hőmérséklet. A tengerekben a nagyobb sürüségű víz hidegebb, így nincs fordított rétegződés (Pruppacher \& Klett, 2001).

A víz fagyásakor a só nem épül be a jég kristályszerkezetébe, hanem zárványként kicsapódik, így az úszó jégtáblák só-zárványokat tartalmaznak. 


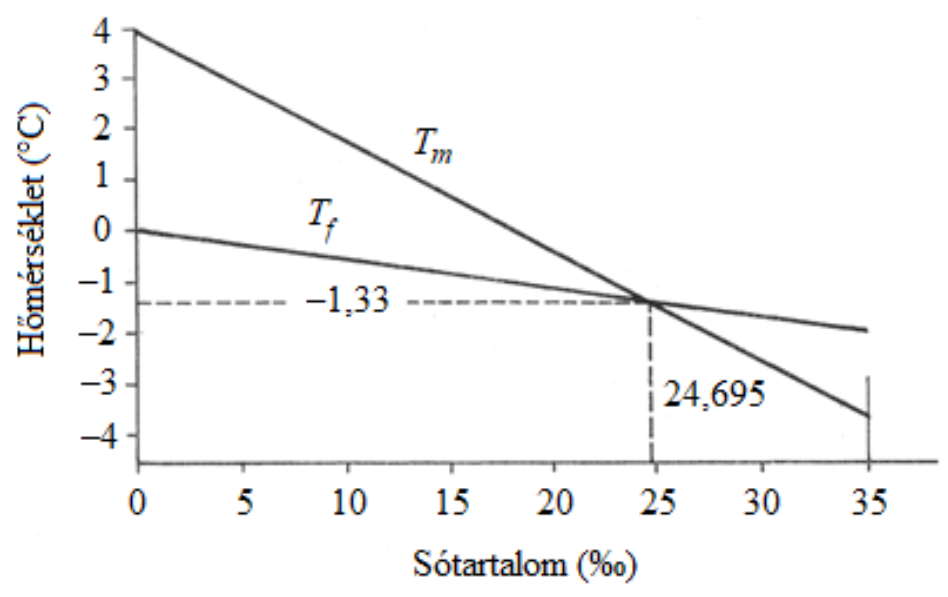

16. ábra: A víz fagyáspontjának $\left(T_{f}\right)$ és a hőmérséklet függvényében $\left(T_{m}\right)$ kialakuló maximális sürüségértékének változása a sótartalommal.

Figure 16: Change of the freezing point $\left(T_{f}\right)$ and the temperature $\left(T_{m}\right)$ where the density is maximal as a function of the salt content.

\section{A víz felületi feszültsége}

A felületi hártyák különleges tulajdonságai régóta ismertek, a szappanhártyákról szóló első írásos emlék jócskán időszámítás elöttről származik (b.c. 3000), babiloni ékírásos kőtábla rögzíti (Rajkovits, 2017). Ennek ellenére a felületi feszültség anyagjellemzőként csak akkor vált tudományosan is megalapozott fogalommá, amikor Eötvös Loránd eljárást dolgozott ki pontos mérésére és megfogalmazta a tiszta folyadékok felületi feszültségének hőmérséklet függését leíró univerzális Eötvös-szabályt. (Eötvös, 1886) Eötvös a felületi feszültséget a folyadékok molekulaszerkezetével hozta kapcsolatba.

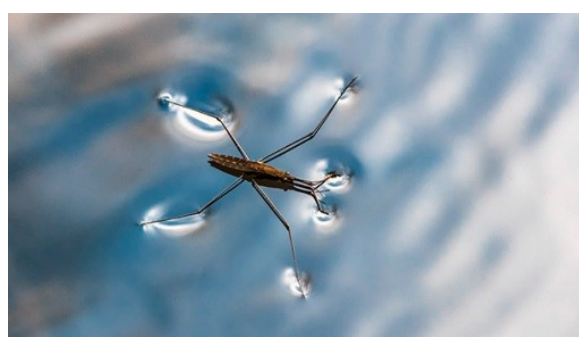

17. ábra: A nyugvó vízhártya rugalmas hártyaként viselkedik, a hullámhossz összemérhető a molnárpoloska lábainak fesztávolságával. [2 - www.cesio.eu]

Figure 17: The surface of the static water is similar to an elastic membrane, where waves can propagate. The wave length is comparable with the span of the feet of the aquatic insects.

$$
\text { [2-www.cesio.eu] }
$$

A víz-levegö határfelületi feszültség értéke a molekulák közötti kohéziós erő, és a hidrogénhíd-kötés következtében kialakuló klaszter szerkezet miatt viszonylag nagy, kb. $72 \mathrm{mN} \mathrm{m}^{-1}$, ennél csak a folyékony fémeké, pl. a higanyé nagyobb (közel $480 \mathrm{mN} \mathrm{m}^{-1}$ ).

A nagy felületi feszültség következménye a víz felszínén kialakuló stabil, deformálható hártya, ami lehetővé teszi bizonyos vízi állatok életét a tavak felszínén. A poloskák, vízimolnárkák, vízipókok a vízen szökdécselve akár $1 \mathrm{~m} \mathrm{~s}^{-1}$ sebességgel is haladhatnak 
(17. ábra). Érzékelni tudják a rugalmas hártyán keltett hullámokat, sőt a hullámhosszat szükség esetén lábaikkal be is tudják mérni. Ez segíti őket a közeledő társak, illetve ellenségek azonosításában (Rajkovits, 2018).

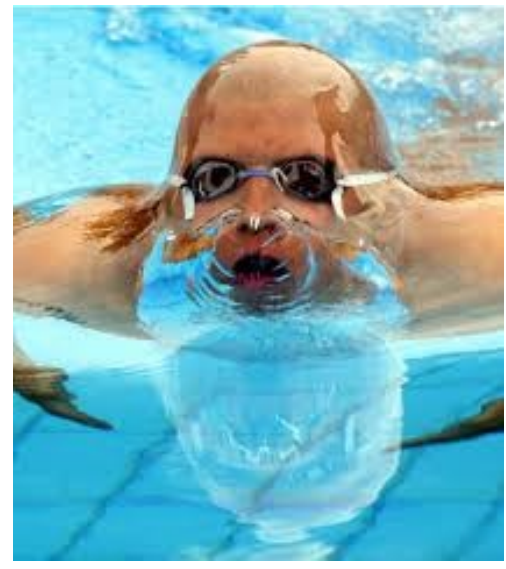

18. ábra: A vízhártya alulról.

Figure 18: Water film from underneath.

A vízhártyát nemcsak felülről, hanem alulról is lehet deformálni, amit sokszor láthatunk az úszóversenyeken készített fotókon. A 18. ábrán jól látszik, hogy az úszó fejével még nem lyukasztotta át teljesen a vízhártyát: az optikai torzulás a vékony vízrétegnek köszönhető. A vízhártya deformációja azonban nem ugyanazzal a mechanizmussal müködik, mint a rugalmas gumihártyáé. Rugalmas anyagok megnyúlása esetén az anyagban a molekulák távolsága megnö, emiatt a belső feszültség is növekszik. Ezért kell nyújtáskor, azaz a rugalmas hártya felületének növelésekor munkát végeznünk. Vízhártya esetében a belső feszültség a felület növekedésekor nem változik, mivel a felület nem nyúlással, hanem új felület képződésével növekszik. Ilyenkor folyadék belsejéből további folyadékrészecskék jutnak a felszínre. Ehhez azért szükséges munkavégzés, mert a felszínen lévő molekulák helyzeti energiája nagyobb, mint a víz belsejében lévőké. A felületi feszültség megértéséhez érdemes ismét megvizsgálni a vízmolekulák között ható erőket. Amint már említettük, a molekulák közötti erők rövid hatótávolságúak. Ezért a víz tömbfázisának belsejében adott molekulát vizsgálva csak egy kicsiny gömbbe, az ún. hatásgömbbe eső molekulák által kifejtett eröket kell figyelembe venni. A hatásgömb szimmetrikus, és a kiválasztott molekulára a többi molekula részéröl ható erök eredője lényegében zérus. (A kiválasztott molekulára ható nehézségi erő ebben az esetben elhanyagolható.) A víz felületén azonban a hatásgömb aszimmetrikussá válik: egyik fele a levegőbe kerül. Ennek ellenére minden felületi molekula egyensúlyi helyzetben lesz. A felületi réteg általában fellazul, a molekulák távolabb kerülnek egymástól, hogy a kohéziós és adhéziós erők egyensúlyba kerülhessenek. Tipikus tévedés az, hogy a felületen lévő molekulákra a folyadék belseje felé ható eredő erő hat, vagy az, hogy a felületi réteg a hatásgömb aszimmetriája miatt ráfeszül a folyadékra. A folyadékhártyát a felületi feszültségből származó erők mindig a hártya síkjában feszítik ki.

A felületi feszültség következménye az is, hogy a vízcseppek hétköznapi körülmények között stabil gömb alakot vesznek fel, így lesz a legkisebb a felületük, és ezzel együtt a felületi energiájuk is. 


\section{A hópelyhek kristályosodása}

Már írtunk röviden a jég hexagonális szerkezetéről, ami a vízmolekulák közötti H-kötések következménye. A H-kötések jelentős szerepet játszanak a hópelyhek morfológiájában is. A hópelyhek nem esés közben megfagyott vízcseppek. Úgy keletkeznek, hogy vízgőzmolekulák kondenzálódnak közvetlenül a szilárd jégfelületre, akárcsak a felhőkben. Alakjuk kristálynövekedési folyamatot mutat. A kristályok makroszkopikus alakja és szimmetriája erősen függ az elemi rácsszerkezettől, a rácsot felépítő atomok illetve ionok kapcsolódási szimmetriájától. A hópelyhek mérete általában néhány $\mathrm{mm}$. A hókristályok tulajdonságait Illy Judit munkája alapján foglaljuk össze (Tasnádi \& Illy, 2018).

A jég egyensúlyi körülmények között szabályos hatszöges kristályokká nő (19. ábra). A hexagonális szerkezetű makroszkopikus kristályoknak két jellemző kristályformája a bázis (0001) és a hexagonális prizma (az alaplap és az oldallap). A hókristályok a felhőkben egészen egyszerü, hexagonális jégkristályként születnek aprócska szennyező magokon. Későbbi fejlődésük a felhő hőmérsékleti és nedvességviszonyaitól függ, kialakulásuk azonban nem egyensúlyi folyamat. A hópelyhek különleges és egyedi képződmények, nincs két egyforma hópehely (20-24. ábra). Bár a születő kristálymagok még nagyon egyformák, már kismértékben eltérő körülmények között is másként fejlődnek, ugyanakkor a hexagonális alakzatot és szimmetriát továbbra is megtartják a kristálycsírák.

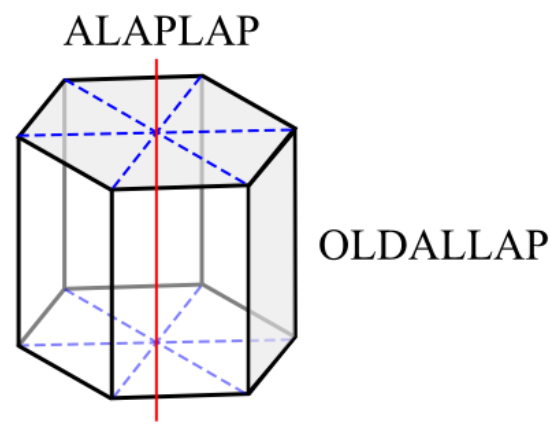

19. ábra: Hexagonális szerkezet.

Figure 19: Hexagonal structure.

A hópelyhek morfológiai (alak szerinti) változatosságát és kristályosodási folyamatát sokan vizsgálták, a jelenségnek nagy irodalma van (Libbrecht, 2007). A hópelyhekröl fényképek alapján készítettek alaktani katalógusokat. A hópelyhek fényképezése nem egyszerü feladat, az idők folyamán többféle technikát dolgoztak ki. Az első hópehely fényképgyüjteményt Wilson Bentley vermonti farmer készítette hobbi fényképészként még a 20. század elején (20.ábra). Közel 5000 felvételt készített fotólemezekre, halála után jelent meg összefoglaló könyve (Bentley \& Humphreys, 1931). Mikroszkóp alatt fényképezett úgy, hogy a sötét háttér előtt lévő kristályokat hátulról világította meg. Részletesebb információk a fényképezés módszeréröl és további felvételek a [3 - snowflakebentley.com] honlapon találhatók.

Ukichiro Nakaya (Nakaya, 1954) volt az első, aki szisztematikusan vizsgálta a hókristályokat és katalogizálta őket. Először állított elő kísérletileg hópelyheket kontrollált laboratóriumi körülmények között, ún. konvekciós kamrában. A fényképek alapján megállapítható, hogy a hópelyhek mind a természetben, mind pedig mesterséges, laboratóriumi körülmények között ugyanolyan típusokban jelennek meg. A fényképek, a lemezes illetve hasáb formájú pelyhek jellegzetes típusait mutatják (21-23. ábra). 

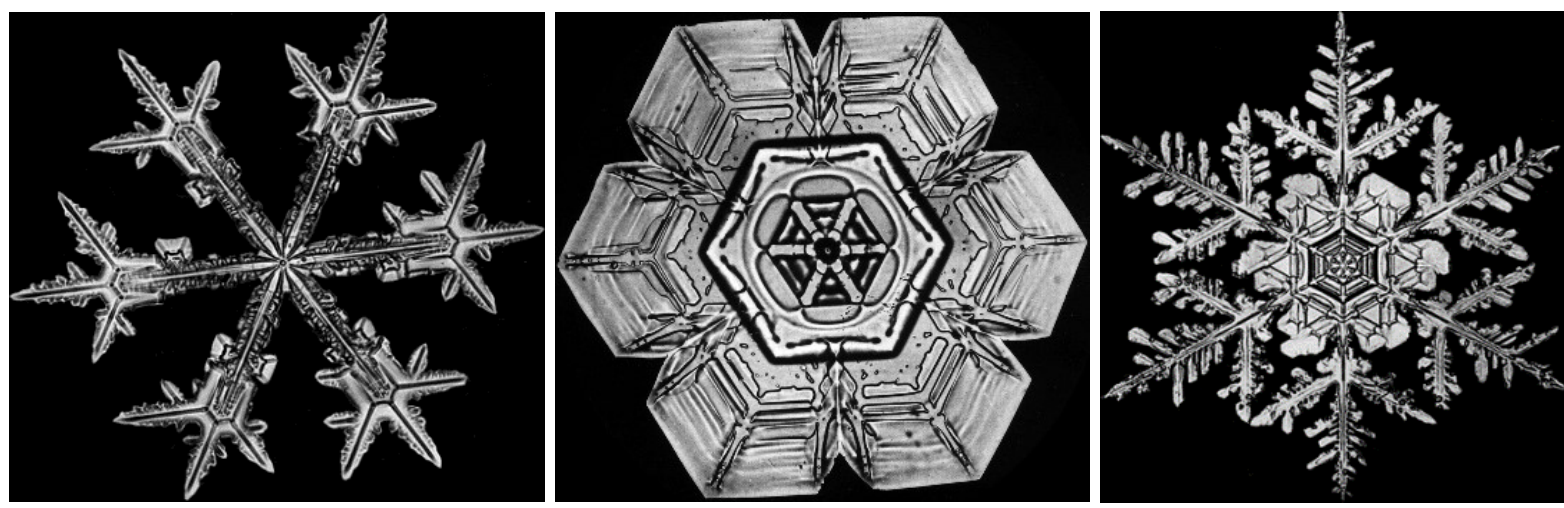

20. ábra: Wilson Bentley felvételei: Jól látszik a felvételen, hogy a hókristályok nem fehérek, hanem átlátszóak (forrás: [4 - en.wikipedia.org]).

Figure 20: Bentley's Photos: They well demonstrate that snowflakes are not white but transparent (source: [4 - en.wikipedia.org]).
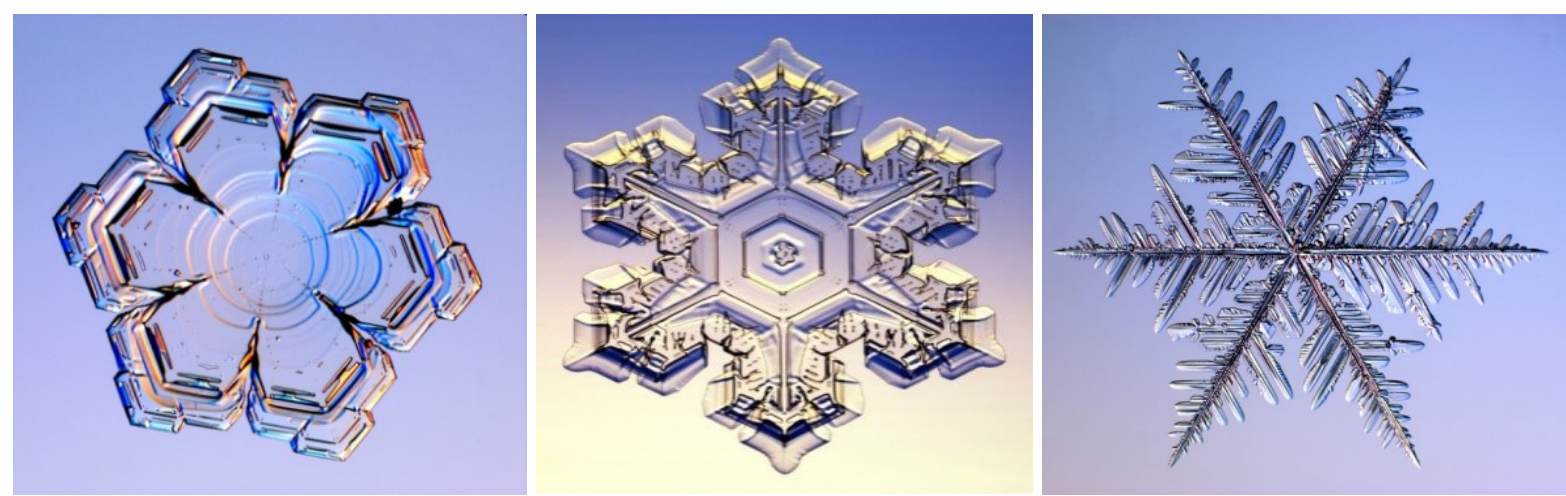

21. ábra: Hatszögletü lemez, csillag lemez és dendrites kristály.

Figure 21: Hexagonal plate, stellar plate and dendritic crystal.
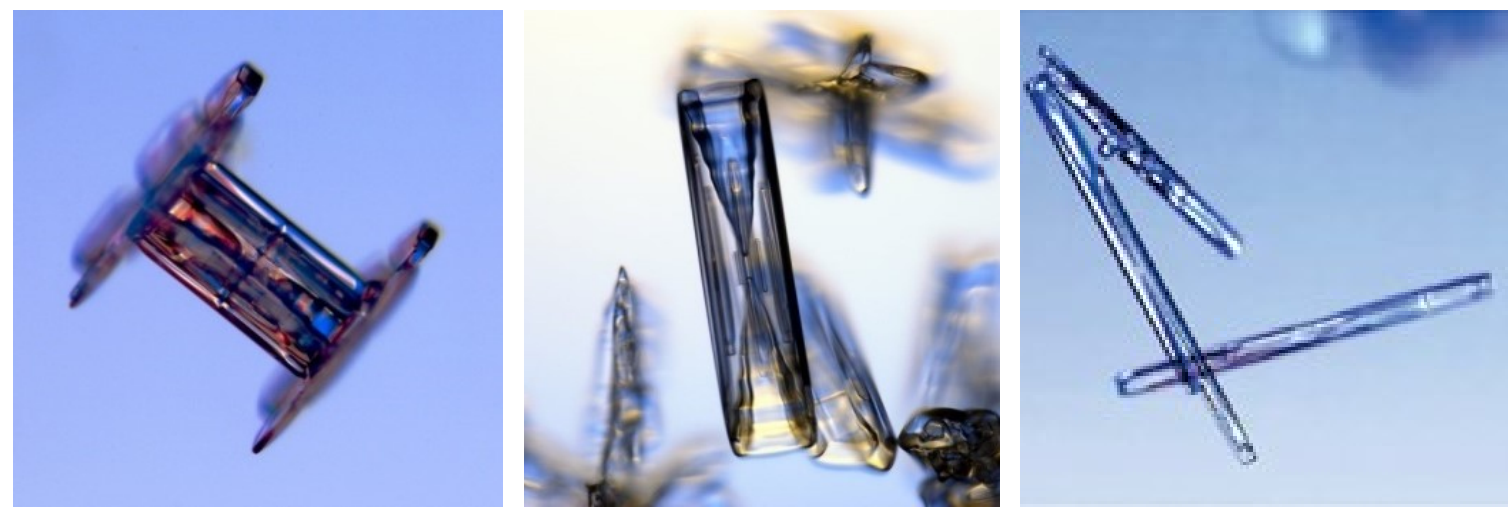

22. ábra: Tömör hasáb, üreges oszlop, tü.

Figure 22: Solid column, hollow column, needle.

Nakaya szisztematikus vizsgálatai azt mutatták, hogy a morfológia alapvetően a hőmérséklettől és a túltelítettség mértékétől függ az alábbi összefoglaló diagram szerint a 23. ábrán bemutatott módon (Czelnai, 1979). 


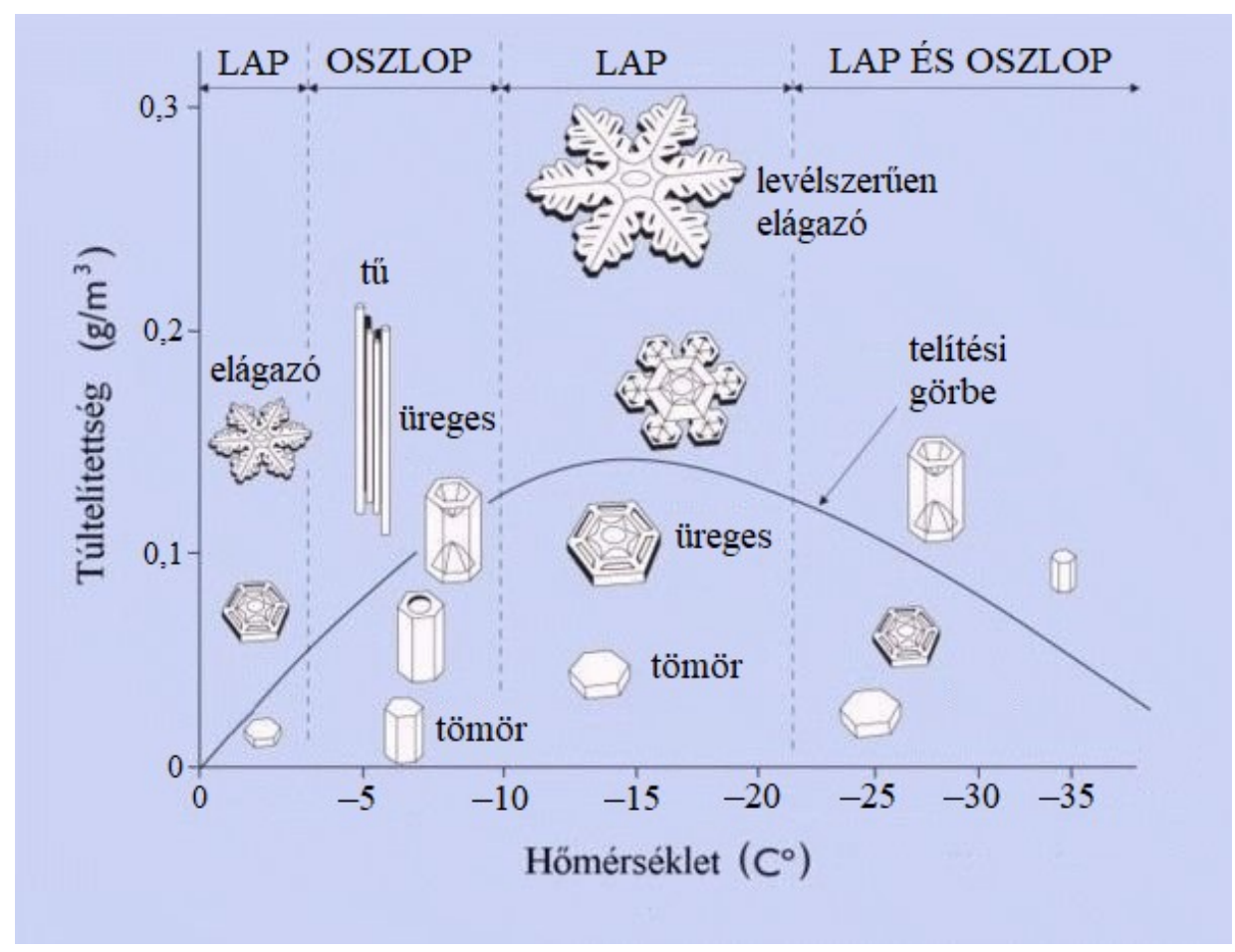

23. ábra: A jégkristályok alakja a hőmérséklet és a túltelítettség függvényében.

Figure 23: Crystal shapes as function of temperature and excess vapor density.

A diagram (23. ábra) jól szemlélteti, hogy

- $T=-2{ }^{\circ} \mathrm{C}$ körül lemez alakú és dendrites kristályok képződnek;

- $T=-5^{\circ} \mathrm{C}$ körül oszlop alakú kristályok figyelhetök meg;

- $T=-15^{\circ} \mathrm{C}$ körül megint a lemez alak dominál, és növekvő túltelítettségnél egyre bonyolultabb a szerkezet;

- $T<-25{ }^{\circ} \mathrm{C}$ esetén pedig vegyesen, lemez és oszlopforma egyaránt kialakul.

A túltelítettség növekedésével a kristályok szerkezeti komplexitása nő. A hőmérséklettől függő morfológiai különbség annak a következménye, hogy a kristályok képződéskor az atomi kapcsolódásoknak megfelelően kialakuló kristálytani síkok a hőmérséklettől függően nem egyforma sebességgel növekednek (24. ábra).

Érdekes, hogy a hópelyhek változatossága a sarkokon megszünik, a különösen hideg és száraz körülmények között a hókristályok nagyon egyszerü formájúak. Ennek köszönhetően jönnek létre a különlegesen szép sarki halojelenségek. 


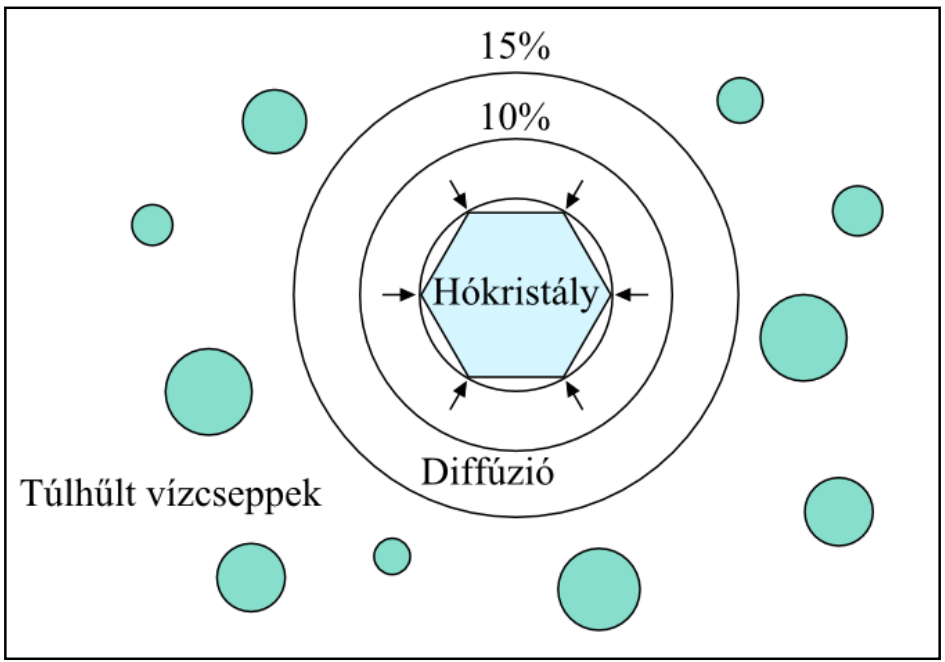

24. ábra: Kristály növekedése nagy túltelítettség esetén.

Figure 24: Crystal growth in case of high excess vapor density.

\section{Áltudományos nézetek, babonák}

A víz hétköznapi jelenléte, ismertsége ellenére különleges tulajdonságaival tápot adott, és ma is tápot ad számos áltudományos nézetnek is. Úgy érezzük, tanulságos lehet ezek közül is néhánynak megemlítése, mert hazánkban is felkapott babonákká váltak.

A víz a leggyakrabban használt oldószer, igy a homeopatikus gyógyszerek alapelemévé vált. A „kutyaharapást szőrivel” elven alapuló homeopátia állítása szerint a betegségek gyógyíthatóak, ha a mérgezést, rosszullétet okozó anyagot óriási hígításban beadjuk a betegnek. A hígítás 20, 50 és akár 200 lépésben is történhet, és minden lépésben 100-szoros. Nyilvánvaló, hogy a „gyógyszer” esetenként már csak legfeljebb egy két molekulát, vagy semmit sem tartalmaz az eredeti anyagból. A homeopatikus gyógyszereknek tudományosan kimutatott hatása nincsen, legfeljebb placebóként alkalmazhatók. A homeopátiáról az Európai Akadémiák Tudományos Tanácsadó Testületének (EASAC) visszafogott állásfoglalása szerint „nem állnak rendelkezésre a homeopátia hatékonyságát alátámasztó, tudományosan elfogadható és reprodukálható bizonyítékok Ez az alternatív gyógyítási módszer [5 - www.urbanlegends.hu] elterjedtsége ellenére egyszerű szélhámosság.

A homeopátiához szorosan kapcsolódik a ,viz memóriájáról” szóló nézet. Az állítás az, hogy a homeopátiás szert hígító víz, még akkor is örzi a hígított szer hatását, ha a vízben az eredeti szer egyetlen molekulája sem található, azaz a víz emlékezik arra, hogy milyen előzetes kezelésen ment keresztül. A kérdés részletes elemzése megtalálható Chaplin már többször idézett honlapján [6 - www1.lsbu.ac.uk]. Itt egyetlen ellenérvet idézünk. A vízben, bár kialakulhatnak molekulacsoportok, az egyes H-kötések élettartama annyira rövid (ps), hogy egyéb szennyező nélkül a víz nem tárolhat hosszabb ideig információt.

Ugyancsak a víz emlékező tulajdonságára alapoznak a PI víz („élővíz”) árusítói és pozitív hatásának hívői is. A PI víz esetén az emlékezést külső mágneses tér hatásának tulajdonítják. Érdemes az interneten elolvasni néhány, a PI viz csodálatos hatását taglaló cikket. Annak ellenére, hogy Riedel Miklós és munkatársai már 1995-ben egyszerü mérésekkel kimutatták, hogy a PI viz és a csapvíz között nincsen lényeges különbség, a babonák tovább élnek és rombolnak [1 - www1.lsbu.ac.uk]. 


\section{Összefoglalás}

A víz különleges tulajdonságaiért alapvetően a hidrogénhíd-kötések és a vízmolekula nagy elektromos dipólmomentuma a felelős. A H-kötések a jégben megszabják a kristályszerkezetet, a folyadékvízben (vagy egyszerüen a vízben) pedig molekulacsoportokat hoznak léte. A H-kötések felszakításához többlet energia befektetése szükséges, ezért a folyadékvíz különösen stabillá válik. Fajhője és latens párolgási hője kirívóan magas lesz. Hasonlóképpen felületi feszültsége is nagy. A H-kötéseknek köszönhető, hogy a víz sürüsége $4{ }^{\circ} \mathrm{C}$-on a legnagyobb, s a jég $9 \%$-kal könnyebb, mint a víz. A víz anomális tulajdonságainak különleges szerepe van a légköri víz körforgásában és rajta keresztül a földi klíma alakításában. Ezekre hoztunk fel példákat, rámutatva a valóságos hatásokra és az áltudományos babonákra.

Köszönetnyilvánítás: A tanulmány elkészítését a Magyar Tudományos Akadémia Tantárgypedagógiai Kutatási Programja támogatta.

\section{Hivatkozások}

Bentley, W.A., Humphreys, W. J., 1931: Snow crystals. Dover Pictorial Archive, 224p. ISBN13: 978-0486202877

Bihari, P., 2012: Müszaki hőtan. EDUTUS Főiskola, Digitális Tankönyvtár.

https://www.tankonyvtar.hu/hu/tartalom/tamop412A/2010-

001742 muszaki_hotan/ch02s02.html

Bodor, E., 1968: Szervetlen Kémia. Tankönyvkiadó, Budapest. 735p. Tankönyvi szám: 44326.

Czelnai, R., 1979: Bevezetés a Meteorológiába I. Légkörtani alapismeretek. Tankönyvkiadó, Budapest. 231p. Tankönyvi szám: J3-1192.

Eötvös, L., 1886: Über den Zusammenhang der Oberflächenspannung mit dem Molekular Volumen. Annalen Der Physik Und Chemie, Neue Folge, 27: 448-459.

https://mek.oszk.hu/03200/03286/html/eotvos1/eotv6.html

https://doi.org/10.1002/andp.18862630309

Geresdi, I., 2004: Felhőfizika. Dialóg Campus Könyvkiadó, Budapest-Pécs, 272p. ISBN: 9639542091.

Libbrecht, K., 2007: The Art of Snowflake: A Photographic Album, (epub) Voyager Press, 208p. ISBN-13: 978-0760347003

Marx, Gy., 1978: Életrevaló atomok. Akadémiai Kiadó, Budapest, 318p. ISBN 9630515431

Nakaya, U., 1954: Snow Crystals: Natural and Artificial. Griffin Books (Stamford, CT, U.S.A.), Harvard University Press, 510p. ISBN-13: 978-0674811515. https://doi.org/10.4159/harvard.9780674182769

Nyilasi, J., 1976: A víz. Gondolat Zsebkönyvek, Gondolat Kiadó, Budapest. ISBN: 9632803442

Ormándi, Zs., 2014: Klasszikus molekuladinamikai szimulációk víz-molekula klaszterekben. BSc Szakdolgozat, ELTE Kémia Intézet, 39p. http://phys.chem.elte.hu/test/szakdolik/2014/OrmandiZsofia_BSc_2014.pdf

Pruppacher, H.R., Klett, J.D., 2001: Microphysics of clouds and Precipitation. Springer, Berlin. 954p. ISBN 978-0-306-48100-0. 
Rajkovits, Zs., 2017: Szappanhártyák és -buborékok tudománytörténete. Fizikai Szemle, 48(4): 121-129. http//www.epa.oszk.hu/00300/00342/00330/pdf/EPA00342 fizikaiszemle-2017-04_121-129.pdf

Rajkovits, Zs., 2018: Fizika az élő természetben. Fizikai Szemle, 68(7-8): 256-263. http://www.epa.oszk.hu/00300/00342/00330/pdf/EPA00342_fizikai-szemle-2018-0708 256-263.pdf

Tasnádi, P., Illy, J., 2018: Víz a légkörben és a talajban. Budapest, Kézirat.

Weidinger, T., Tasnádi, P., 2015: Víz a légkörben. Magyar Kémikusok Lapja, LXX(11): 344-349. HU ISSN 1588-1199 (online), https://www.mkl.mke.org.hu/images/stories/downloads/2015/2015_11.pdf

Weidinger., T., Tasnádi, P., 2020: Víz a légkörben. Egyetemi Meteorológiai Füzetek, 32 (Szerk.: Weidinger, T.): 81-104. (Jelen kiadványban.) https://doi.org/10.31852/EMF.32.2020.081.104

Zhang, J., Chen, P., Yuan, B., Ji, W., Cheng, Z., Qiu, X., 2013: Real-Space Identification of Intermolecular Bonding with Atomic Force Microscopy. Science, 342(6158): 611-614. https://doi.org/10.1126/science. 1242603

\section{Internetes hivatkozások}

[1 - www1.lsbu.ac.uk]: A víz anomális tulajdonságai (Chaplin honlapja alapján):

(http://www1.lsbu.ac.uk/water/water_structure science.html)

[2 - www.cesio.eu]: Molnárpoloska a vízen, és ami mögötte van:

http://www.cesio.eu/index.php/about-surfactants/what-are-surfactants

[3 - snowflakebentley.com]: A hópelyhek fényképezéséről: http://snowflakebentley.com/

[4 - en.wikipedia.org]: Wilson Bentley - információk az Internetről:

https://en.wikipedia.org/wiki/Wilson_Bentley

[5 - www.urbanlegends.hu]: Európai Akadémiák Tudományos Tanácsadó Testületének

(EASAC) állásfoglalása: http://www.urbanlegends.hu/2017/09/europai-tudosokallasfoglalas-homeopatia-easac/

[6 - www1.lsbu.ac.uk]: A babonák tovább élnek, a PI víz és a csapvíz között nincsen lényeges különbség: http://www1.lsbu.ac.uk/water/memory_of_water.html\#r1206

\section{ORCID}

Tasnádi P. (D) https://orcid.org/0000-0002-7813-5269

Weidinger T. (D) https://orcid.org/0000-0001-7500-6579 